\title{
MULHERES DA LUZ: \\ UMA ETNOGRAFIA DOS \\ USOS E PRESERVAÇÃO \\ NO USO DO CRACK
}

SELMA LIMA DA SILVA

Dissertação de Mestrado apresentada ao Departamento de Práticas de Saúde Pública

da Faculdade de Saúde Pública da Universidade de São Paulo para obtenção do Grau de Mestre.

Área de concentração:

Serviços de Saúde

ORIENTADOR: PROF. Dr. RUBENS DE CAMARGO FERREIRA ADORNO.

SÃO PAULO

2000 
Autorizo exclusivamente para fins acadêmicos e científicos, a reprodução total ou parcial desta dissertação, por processo fotocopiadores.

Assinatura:

Data: 
Ao meu filho Ébano 
Aos meus pais Maria e José e a minha sobrinha Aline

(In memoriam) 


\section{AGRADECIMENTOS}

Ao Prof. Associado Rubens C. F. Adorno pelas orientações dadas, pela amizade e compreensão que pude contar em alguns momentos difíceis .

Aos Membros da Banca Dr. Alberto O. A. Reis e Eduard MacRae pelas valiosas contribuições e bibliografia.

A. Dra. Augusta Tereza Alvarenga e Dra Maria da Penha Vasconcelos, por toda ajuda e sugestões. Ao Dr. Ivan França Junior pela disponibilização do mapa da cidade de São Paulo.

Ao CNPq (Conselho Nacional de Desenvolvimento Científico e Tecnológico), pela bolsa de estudo que me permitiu a execução deste trabalho

As Mulheres da Luz e a Casa de Convivência Luz

Um agradecimento muito especial a amiga Giliana Betini, que me ajudou em momentos muito críticos. Não fosse por ela talvez não tivesse conseguido concluir esse trabalho.

A minha família, em especial as minhas irmãs Sandra e Silene por todo apoio e incentivo.

A Heidi Cerneka e Sabine Röck pelos dias e noites em que caminhamos pela região da Luz e também pelas discussões que muito me ajudaram e principalmente pela amizade conquistada. Aos amigos Oswaldo Rosa e Celso Luiz Moro por toda ajuda e incentivo.

As amigas Mara de Mello Faria, Rosa de Lourdes Azevedo, Elisabete Gonçalves, Michelle Mayers pelo apoio.

À Elba Barreto Carvalho, Leandro Firmino Cleto e lara Aparecida de Macedo pelo carinho e atenção. 


\section{RESUMO}

Silva SL. Mulheres da Luz: uma etnografia dos usos e preservação, no uso do crack.. São Paulo; 2000. [Dissertação de Mestrado - Faculdade de Saúde Pública da USP].

Objetivo. Conhecer as relações que se estabeleceram entre a prática da chamada baixa prostituição feminina e a prática do uso de crack no local conhecido como crackolândia, na região da Luz, zona central da cidade de São Paulo, no passado conhecida como "boca do lixo". Métodos. Realizou-se pesquisa etnográfica junto as mulheres que freqüentam e/ou fazem programas na região, observando as relações entre as práticas da prostituição e do uso do "crack". Resultados. A entrada do crack ocasiona conflitos entre as mulheres que se prostituem e o utilizam e as não usuárias, pelo fato de cobrarem menos pelo preço dos programas. Existe uma maior exposição para os problemas de saúde em especial para as DSTS/AIDS, ocasionados não só pelo uso do "crack", mas também pela situação de pobreza e crenças do que seja ser saudável. Contudo, observou-se que as mulheres usuárias do crack se valem de estratégias para o controle do uso e cuidados com o corpo. Conclusão. Verificou-se que o consumo de "crack" mais que uma adesão a uma substância é uma adesão a uma forma de viver no circuito da rua, também observou-se a existência de algumas formas mesmo que incipiente - de cuidados com a saúde e o corpo dentro desse estilo de vida. Diante disto, propõe-se uma forma de atuação mais efetiva para melhorar a qualidade de vida dessas mulheres, através de estratégias que elas mesmas já desenvolvem, trabalhando numa perspectiva de redução de danos para o consumo de "crack".

Descritores: prostituição feminina, uso de crack, estigmatização, auto- cuidados, redução de danos. 


\section{SUMMARY}

Silva, S.L. Women from the Luz quarter: an ethnography on the ways of using it and self-care health practices, at the use of crack. São Paulo, 2000. [Master's monograph - University of São Paulo School of Public Health]. São Paulo, State of São Paulo, Brazil.

Objective: To get to know the relationships established between the practice of the so-called female low-prostitution and the use of crack in a place known as "Crack-land", in the Luz quarter, previously known as "the Garbage's Mouth", down-town São Paulo city, State of São Paulo, Brazil. Methodology: An ethnographical research was carried out along with women who attend regularly and/or engage themselves in sexual programs within this region, observing the relationships between prostitution practices and the use of crack. Results: The entering of the crack into this region causes conflicts among the female prostitutes who use the drug and those who do not, since the fees charged by the first ones for sexual programs are lower than those charged by the non-users. There is a greater exposition to health problems, in special to STD/AIDS, caused not only by the use of crack but also by the condition of extreme poverty they found themselves in and the beliefs on what they consider as being healthy. However, it was observed that the women who use crack avail themselves of some strategies concerning the control of the use of their own bodies and self-care health practices. Conclusion: It was observed that, more than addiction to a substance, the consumption of crack is an adhesion to a way of living within the streets' circuit. The existence of some forms of self-care - although incipient - related to their health and their own bodies within this life-style was also noticed. In the face of these findings, it would be worth studying a more effective way of proceeding in order to improve the quality of life of these women by means of strategies that they themselves already develop, working within a perspective of reducing the health damages associated with the consumption of crack.

Descriptors: female prostitution, use of crack, stigma, self-care, risk reduction. 


\section{ÍNDICE}

INTRODUÇÃO

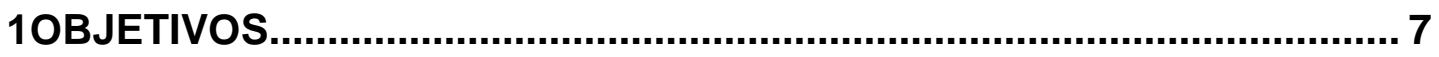

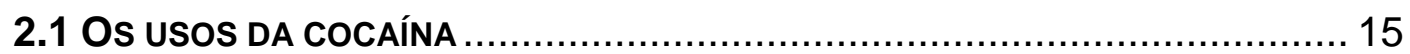

2.2 A RELAÇÃO ENTRE PROSTITUIÇÃO, USO E TRÁFICO DE DROGAS.................. 23

2.3 HISTÓRICO DA PROSTITUIÇÃo NA REGIÃO DA LUZ .................................. 26

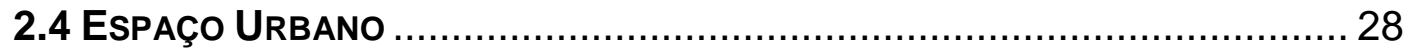

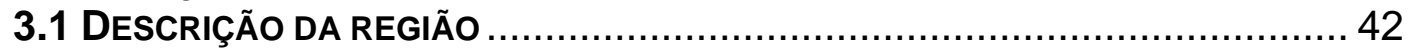

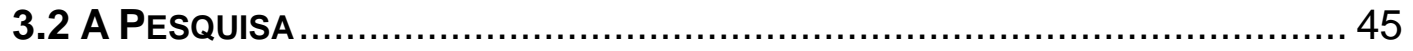

4 CARACTERIZAÇÃO DA REGIÃO DA PESQUISA …............................. 47

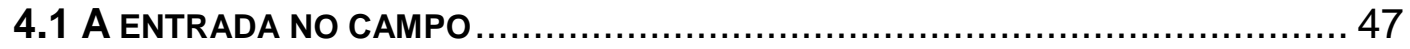

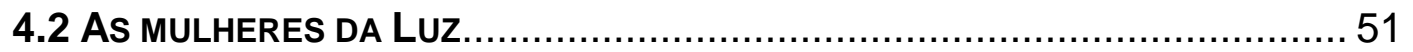

5 ESTRATÉGIAS PARA O USO DE DROGAS …….................................. 71

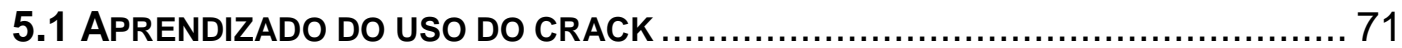

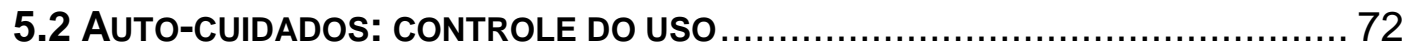

5.3 HÁBITOS ASSOCIADOS AO USO DE CRACK...................................... 75

5.4 A NÓIA: EFEITO NÃO DESEJADO …….......................................... 77

5.5 DIFERENÇA ENTRE HOMENS E MULHERES NO USO E TRÁFICO DE CRACK $\ldots . . .79$

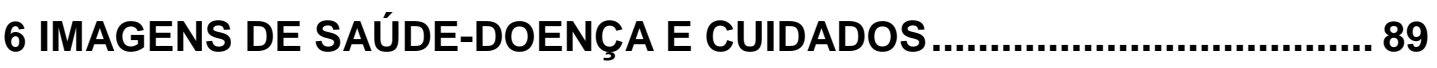

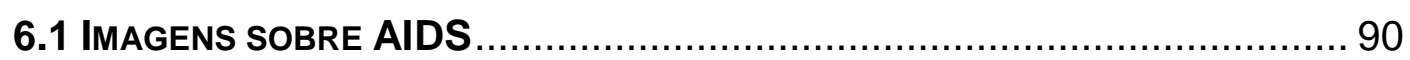

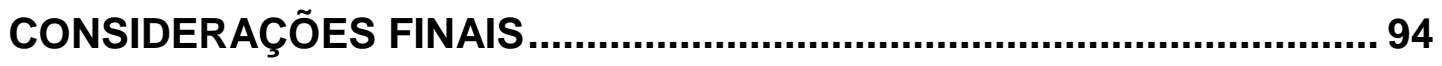

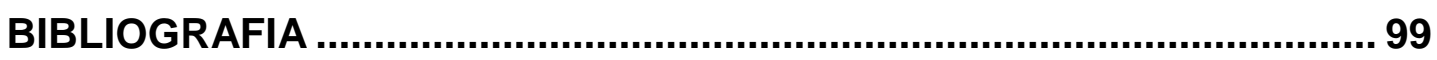

ANEXOS

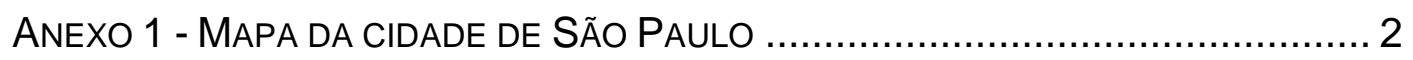

ANEXO 2- REGIÃO PERCORRIDA........................................................ 3 


\section{INTRODUÇÃO}

O debate sobre a questão das drogas designadas como ilícitas no país tem assumido um caráter alarmista. A maioria das pesquisas desenvolvidas, tanto no Brasil como em outros países, têm sempre por objetivo traçar um perfil epidemiológico, levando em conta os malefícios físicos e a violência associada ao uso e tráfico de drogas. Seguindo esta mesma lógica, o crack, substância derivada da cocaína, vem ocupando grande espaço na mídia - jornais, revistas, noticiários de tevê em horário nobre - sendo apontada como uma droga devastadora. Tal preocupação vem alimentando a discussão em torno de políticas que têm se caracterizado como repressivas e preventivas ao consumo de drogas, como também tem incentivado a polêmica sobre repressão versus legalização ou descriminalização de seu uso.

Cabe lembrar que não se deve pensar o fenômeno do uso de drogas apenas em seus aspectos farmacológicos ou epidemiológicos, como geralmente tem sido a tônica dos escassos trabalhos produzidos, mas sim levar também em conta os fatores farmacológicos relacionados a sua atuação no organismo, o estado psíquico de quem a utiliza e o contexto sociocultural onde ocorre esta utilização. Entender este contexto significa considerar que a busca dos efeitos desejados pode estar vinculada, também, ao circuito que os oferece e à forma de conduta apropriada para a circulação nesse espaço, construindo-se um estilo e uma estética próprios que possibilita a identificação com seus pares e pelos "outros", estabelecendo-se um padrão de sociabilidade. E este padrão, por sua vez, vai estar se consolidando através das representações sociais presentes na sociedade, instaurando-se, assim, uma reflexividade social. GIDDENS (1996) define a reflexividade como o conhecimento (científico ou não) que, não sendo mais privilégio apenas dos "peritos", circula por toda a sociedade, fazendo parte do seu cotidiano e influenciando nas decisões tomadas e, por conseguinte, nas práticas sociais, mesmo que esse conhecimento seja incorporado de maneira imperfeita. 
Portanto, é importante atentar para o fato de que não existe um único, mas diversos usos de drogas, e levar em conta as diferenças e multiplicidades dos indivíduos e o significado que atribuem a esse uso. Os estudos de natureza qualitativa, como os antropológicos, constituem um referencial teórico/instrumental adequado para essa investigação, mas tal forma de abordagem ainda é bastante incipiente no Brasil, especialmente quando se trata da temática do consumo feito por mulheres, cuja condição de vida pode ser definida de "exclusão social" e, mais especificamente, no tocante ao segmento populacional feminino que tem como atividade a prostituição.

Com relação ao consumo desse grupo de mulheres existem ainda outras questões de saúde que merecem atenção, principalmente para este segmento, que é o risco materno-infantil associado ao uso de cocaína/crack e pobreza.

Alguns estudos realizados nos EUA, dentre os quais KOREM et. al. (1994), GAZAWAY (1994) e HAWLEY et. al. (1995), demonstraram que, do "ponto" de vista farmacológico, a cocaína provoca efeitos deletérios na gravidez, no parto e no desenvolvimento neonatal. Insuficiência úteroplacentária, retardo de crescimento intra-uterino, microcefalia, parto prematuro e descolamento de placenta estão associados ao uso de cocaína, bem como hemorragias e quadros de eclâmpsia, que podem ocasionar óbito fetal intra-uterino em casos mais graves, trazendo alto risco de morte materna. Ocorre também contração uterina persistente, havendo relatos de aumento de abortos espontâneos em usuárias da cocaína. Em alguns casos de interrupção do uso de cocaína no início da gravidez, o risco de parto prematuro ou descolamento placentário não diminui.

Quanto aos efeitos nos neonatos encontrados nesses estudos, descreveram-se algumas malformações neurológicas e ósseas graves e a possibilidade de todos os sistemas orgânicos serem afetados. Foram descritos também a presença de tremores, taquipnéia (respiração rápida), hipertonia (aumento da tensão muscular), sono anormal, e, ocasionalmente 
convulsões. Um efeito recorrente foi a microcefalia, de conseqüências incertas. Os estudos relataram, ainda, a hiperflexão da cabeça e movimentos excessivos diante da estimulação, estando relacionados com a duração do abuso de cocaína. Não ficaram bem estabelecidas as conseqüências futuras no desenvolvimento intelectual do neonato exposto a essa condição.

Dos autores consultados, ZUCKERMAN (1992) e KEARNEY (1996), desenvolveram uma análise diferente sobre a duração dos efeitos no neonato, expressando críticas sobre os resultados de alguns trabalhos médicos, por estes não apresentarem uma metodologia adequada, pois só pesquisaram mães "dependentes" e pobres, excluindo as mães pobres não dependentes em suas amostras. ZUCKERMAN (1992) apoiou-se em trabalho de Chasnoff que afirmou não existirem diferenças significativas no desenvolvimento de crianças até 2 anos, na escala Baylei, comparado com controles da mesma classe social sem exposição a drogas. Os autores chamam atenção para o que, em suas opiniões, é o real problema, ou seja, a pobreza e a falta de acesso a um bom pré-natal, remédios e alimentação adequada e de um bom atendimento por parte dos profissionais da saúde.

Cabe ressaltar que, além dos riscos descritos, e esse grupo populacional ser tomado como problema, na ótica "materno-infantil", pela exposição à cocaína e ao crack, talvez um dos fatores mais preocupantes é que esta situação aumenta a vulnerabilidade para as Doenças Sexualmente Transmissíveis e a Síndrome da Imunodeficiência Adquirida (DSAs/AIDS). A noção de vulnerabilidade que perpassa atualmente a questão da infeção pelo Vírus da Imunodeficiência Adquirida (HIV) consiste em uma revisão crítica, adotada nos EUA, visando superar o conceito de grupo de risco adotado pela epidemiologia no inicio da epidemia que, de certa forma, contribuiu para criar um estigma da doença.

(....) a noção de vulnerabilidade busca estabelecer uma síntese conceitual e prática das dimensões sociais, políticoinstitucionais e comportamentais associadas às diferentes 
susceptibilidades de indivíduos, grupos populacionais e até mesmo nações, à infeção pelo HIV e às suas conseqüências indesejáveis (doença e morte). Ela não visa distinguir aqueles que têm alguma chance de se expor à AIDS, mas fornecer elementos para avaliar objetivamente as diferentes chances que todo e qualquer indivíduo tem de se contaminar, dado o conjunto formado por certas características individuais e sociais de seu cotidiano, julgadas relevantes para a maior exposição ou menor chance de proteção diante do problema. (AYRES 1996, p. 5)

Ainda para AYRES (1996) esta noção

(...) procura particularizar as diferentes situações dos sujeitos (individuais e/ou coletivos) diante da epidemia da AIDS em três planos analíticos básicos: o individual, o programático ou institucional, e o social. Desenvolvimentos ainda mais recentes têm procurado estender o uso da noção de vulnerabilidade para outros aspectos ligados à saúde de populações e estratégias preventivas, como a questão da violência nas relações de gênero e, agora conosco, ao problema das drogas. (p. 5).

O conceito de vulnerabilidade tem como pressuposto compreender a relação que se estabelece entre o indivíduo, o acesso à informação, educação, políticas e serviços, em um nível macro, entendendo que algumas práticas por ele adotadas são fruto da carência deste acesso. Busca, dessa forma, eliminar o estigma associado ao indivíduo, em que tais práticas configurariam um risco para o resto da sociedade. Esse conceito porém, parece não levar em consideração que tais práticas podem estar sendo determinadas não só pela falta de acesso, mas pelos significados atribuídos a elas, sejam estas, sexuais ou de consumo de drogas. Portanto, não basta oferecer mais acesso, pura e simplesmente, pois o padrão de vida saudável 
proposto pelo pensamento médico-sanitarista pode não ser o mesmo na perspectiva do indivíduo.

No passado, o discurso médico viu a questão da prostituição como um problema moral. Atualmente, apesar de terem sido lembradas a partir do advento da AIDS, o discurso da saúde foi um dos que mais avançaram no sentido do respeito às práticas divergentes, incluindo aí o uso de drogas, principalmente as injetáveis. Tal fato se deu em função do envolvimento de novos atores sociais no cenário público, que adotaram uma postura de enfrentamento diante das demandas não atendidas pelas políticas públicas. Dentre eles, destacam-se as organizações não-governamentais (ONGs), que representam, de certa forma, uma resposta de mobilização da sociedade civil frente à problemática colocada pela AIDS.

Mas ainda se tem muito a caminhar, pois tanto sobre a prática da prostituição como a do uso de drogas pesa julgamento moral e estigmatizante. E o crack, da mesma maneira, como um tipo de consumo feito por pessoas que estão socialmente excluídas, não é visto como um problema de sócio-sanitário, mas como uma questão de segurança pública.

Diante disto, a perspectiva desse estudo foi a de conhecer a relação que se estabeleceu entre essas mulheres e o consumo de crack com objetivo de descobrir o papel que este ocupa em suas vidas e se esse uso mostra, mais que uma adesão à substância, adesão a uma forma de viver no circuito da rua. Também buscou verificar a existência de alguma forma, mesmo que incipiente, de cuidados com a saúde e o corpo, no contexto desse estilo de vida. Desta maneira, poderia se pensar em uma forma de atuação mais efetiva para melhorar a qualidade de vida dessas mulheres, por intermédio de estratégias que elas mesmas já desenvolvem, trabalhando numa perspectiva de redução de danos para o consumo de crack.

A proposta de redução de danos reconhece que as pessoas continuarão a se utilizar de substâncias psicoativas, como sempre o fizeram ao longo da história. Ela aceita essa 
realidade, tentando minimizar 0 dano eventualmente provocado, tanto para os indivíduos como para o conjunto da sociedade. (O'HARE 1994, p.67).

O conceito de redução de danos nasceu da observação que a proibição de uma prática prazerosa, termina por gerar maiores problemas a seus praticantes, primeiro por não reconhecer o que ela representa para os usuários e, segundo, porque a proibição, no caso das drogas, traz dificuldades para que os usuários consigam obtê-las. Por ser uma prática ilícita, os usuários podem sofrer punições sendo, assim, estigmatizados.

Essa abordagem já vem sendo utilizada em várias partes do mundo, inclusive no Brasil, com usuários de drogas injetáveis conseguindo bons resultados (O'HARE 1994, RILEY et. Al. s/d). Faz-se necessário agora, ampliar essa perspectiva para o uso de outras substâncias. Do ponto de vista da saúde pública, tratar essa questão sobre esta ótica, além de pertinente, parece apontar para uma melhor qualidade de vida para os usuários, de uma forma geral, e para o grupo de mulheres mencionado anteriormente, em particular.

No primeiro capítulo, são apresentados os objetivos que nortearam o estudo. No segundo, discuti-se como o tema prostituição e o uso de drogas, neste caso, a cocaína, aparece e é tratado na sociedade e também, como alguns locais se configuram como de exclusão na região central da cidade de São Paulo. No terceiro capítulo, descreve-se a opção metodológica que norteou a pesquisa. A caracterização da região e dos atores sociais pesquisados é apresentada no quarto capítulo. No quinto, descrevem-se as estratégias desenvolvidas pelas mulheres para o uso do crack, em que desenvolvem formas de utilização menos danosas à saúde. No sexto capítulo, são descritas as imagens sobre saúde e doença observadas no trabalho de campo. Com base nas observações e no referencial teórico utilizado, discuti-se, nas considerações finais, uma proposta de abordagem da problemática do uso do crack, visando a melhora da qualidade de vida do usuário. 


\section{BJETIVOS}

\subsection{OBJETIVO GERAL}

Conhecer as relações que se estabeleceram entre a prática da chamada baixa prostituição feminina e a prática do uso de crack no local conhecido como crackolândia, na região da Luz, zona central da cidade de São Paulo, no passado conhecida como "boca do lixo". Buscando entender a importância do uso do crack e qual papel ele ocupa em suas vidas e como se articula a sociabilidade nesse espaço.

\section{OBJETIVOS ESPECÍFICOS}

Identificar a origem, idade e história de vida dessas mulheres.

Identificar a existência de rituais de iniciação e aprendizado do uso do crack.

Identificar os significados por elas atribuídos ao uso do crack, e a existência de procedimentos de controle do uso e a existência de cuidados com a saúde e o corpo.

Mapear os locais preferidos para o consumo do crack e os códigos para freqüentar os espaços de negociação dos programas e uso de crack. 


\section{PROSTITUIÇÃO E DROGAS}

Os vários estudos existentes sobre a prostituição feminina, dentre os quais destacam-se GASPAR (1985); ENGEL (1989); MORAES (1995); SEVERINO (1992), não tiveram como objeto central a relação prostituição e uso de drogas. Alguns estudos das décadas de 20 a 60 (MORAES, 1921; MAFFEI 1951), de natureza médica e jurídica, chegaram a mencionar a conexão, mas sempre culpabilizando a figura da prostituta como disseminadora não só de doenças sexualmente transmissíveis, mas também do "vício" das drogas. Em alguns desses estudos a questão era vista como parte integrante do caráter "desse tipo de mulher". A mulher que se prostituía o fazia por ter "um espírito fraco", logo, todas as outras fraquezas eram decorrentes dessa fraqueza inicial.

Pode-se referir que a prostituição sempre foi estigmatizada pelo fato de estar associada à disseminação de doenças venéreas, ao uso e tráfico de drogas e, ainda, à violência de uma forma geral, e a área da saúde não esteve imune a esta visão.

\section{O discurso médico-sanitário}

Uma grande parte dos autores consultados, como MORAES (1921) e MAFFEI (1951),entre outros, manifestaram interesse pelo tema, muito mais pelos problemas sanitários e de ordem moral que suscitava do que propriamente pela figura da prostituta ${ }^{1}$.

O discurso médico-sanitário do início do século era produzido pelo olhar masculino, tanto sobre o que se esperava da figura feminina, como sobre a prostituição feminina. $\mathrm{Na}$ atualidade nota-se que esse discurso ainda ecoa no imaginário social norteando as práticas de muitos policiais e

\footnotetext{
1 Segundo Gaspar (1985), uma vasta literatura sobre o tema prostituição pode ser encontrada. Em seu trabalho encontrou cerca de 162 títulos, os quais classificou de acordo com a postura dos respectivos autores. Dentre estes, encontram-se os de cunho biográfico, os de interesse no campo da medicina, jurídico e aqueles da área das ciências sociais.
} 
figurando em artigos jornalísticos como as responsáveis pelo aumento da marginalidade em algumas regiões da cidade.

A prostituição nunca foi aceita pela sociedade, mas sempre tolerada. Cabe ressaltar que uma das teses mais presentes nesses estudos foi a de que a prostituição, apesar de ser uma "anormalidade", um "vício", era considerada um "mal necessário" porque, apesar de indecorosa, protegia as mulheres "honestas" e a família dos instintos sexuais masculinos incontidos. Esta afirmação encontrada nos autores referidos acima, utilizava-se das colocações de Santo Agostinho e de Santo Tomás de Aquino, que versavam sobre a necessidade de tal mal para a manutenção da ordem social vigente, como justificativa de suas opiniões sobre a prostituição.

Assim como o verdugo, por repugnante que seja, ocupa um posto necessário na sociedade, assim as prostitutas e seus similares por mercenárias, vis e imundas que pareçam, são também necessárias e indispensáveis na ordem social. Retirai as prostitutas da vida humana e chegareis ao mundo da luxuria. (apud LEME 1926, p.145 )

Retirem-se as cloacas da cidade e tudo se encherá de imundice. Retirem-se as meretrizes e tudo se encherá de libido. (apud LEME 1926, p.145)

Nota-se que ocorria uma preocupação com a regulamentação sexual como forma de controle social para o bom andamento da sociedade. Os estudos citados visavam entender o que levava uma mulher a se prostituir, discutindo as possíveis causas.

Algumas explicações foram encontradas em trabalhos médicos apresentados no Departamento de Medicina Legal, que tinham como objetivo propor medidas de prevenção às doenças venéreas, visando um controle maior da prostituição, pois acreditavam ser utópico sua erradicação (LEME, 1926; LOPES, 1973). As causas apontadas para esta situação 
seriam: a pobreza, uma infância marcada pela violência doméstica causada pelo alcoolismo, um "mal passo" dado pela mulher "entregando-se" a um homem antes do casamento, por fragilidade emocional ou debilidade mental, por espírito fraco e também por vício, ou seja, um instinto sexual não dominado, aos quais se associavam como causa ou efeito indiscriminado das mais variadas causas.

A sociedade vivia em um dilema, não podia penalizar a prática da prostituição visto que esta não era (e ainda não é) considerada crime, por outro lado buscavam maneiras de vigiá-la e restringi-la.

Em uma palestra transcrita no Boletim da Repartição Sanitária PanAmericana, da qual o Brasil fazia parte, sobre prostituição e higiene mental, proferida por um médico em um hospital de Washington, D.C., o trecho a seguir, demonstra a forma como o tema era tratado:

(...) acredito que o aspecto da debilidade mental é um aspecto lógico deste problema. É um aspecto concreto (....) do problema a respeito do qual sabemos alguma cousa e a respeito do qual já temos methodos de ataque razoavelmente definidos. $O$ que se deve fazer com indivíduos de espirito fraco, prostituta ou qualquer outra espécie de pessoa cuja conduta seja anti-social, é collocar essa pessoa em uma instituição para alli ser conservada, e acredito que em uma campanha que seja dirigida no sentido da prostituta esta é a medida mais obvia que se possa tomar.(....) de resto não podemos tratar do próprio problema da prostituição como sendo distincto da questão de moléstia venereas. (REPARTIÇÃO SANITÁRIA PAN - AMERICANA 1925, p.256)

LEME (1926) responsabilizava a prostituta pela transmissão das doenças venéreas conforme verificamos abaixo: 
A prostituta é tudo na transmissão das moléstias venéreas, no contagio direto entra em $95 \%$ dos casos; e o contato sexual que infecta o homem são é sempre tido com uma prostituta! Se assim é, não menos certo é que a meretriz deve ter recebido a infecção de outro homem, que por sua vez a recebera de outra rameira, e assim temos fechado o circulo vicioso. (p. 178)

Observa-se que ocorria uma preocupação em tipificar a prostituta, Lombroso e Ferrero citados por LOPES (1973), inspirados na antropologia criminal, afirmaram que:

a prostituta possui exatamente as mesmas características que o criminoso: a mesma falta de sentido moral; a mesma dureza de coração; o mesmo gosto precoce do mal; a mesma indiferença à infâmia social que faz com que um suporte a condição de marginal e ela, a de mulher perdida; a mesma imprevidência; mobilidade; tendência à preguiça; o mesmo gosto por prazeres fáceis, pela orgia, pelo alcoolismo; a mesma ou quase a mesma vaidade. A prostituição não é senão o lado feminino da criminalidade, e tanto é verdade que prostituição e criminalidade são dois fenômenos análogos, ou, por assim dizer, paralelos, que em suas extremidades se confundem. A prostituta seria então, do ponto de vista psicológico, uma criminosa. Se não comete crimes é por fraqueza física, pela inteligência escassa, pela facilidade em adquirir aquilo que deseja pelos meios mais fáceis. A prostituição representaria a forma específica da criminalidade feminina. (apud LOPES 1973, p.38).

Os autores citados analisaram processos de crimes cometidos por prostitutas ou com a ajuda das mesmas, o que mostra o viés de seu estudo, exatamente como aquele que GASPAR (1985) encontrou em outros 
trabalhos de juristas que versavam sobre a prostituição na França; em ambas as situações, tratavam-se de casos que foram levados à justiça, porém, segundo ela, poderiam ser considerados como "casos escabrosos e, sem dúvida, não tão comuns." (p. 65) A obra desses autores revelava, como característica marcante, "uma preocupação em intervir na legislação para melhor proteger as prostitutas da exploração" (p. 65; 66), ou para puni-las.

Em estudos desenvolvidos, desde a década de 70 até hoje, por membros vinculados à igreja ou às pastorais ${ }^{2}$, tem se buscado uma explicação para as causas da prostituição na pobreza, maus tratos e abuso sexual em casa, falta de preparo para conseguir trabalho, dependência de drogas e álcool. Está presente nestes trabalhos a tentativa de resgatar a dignidade dessas "madalenas" para que troquem a prostituição por um trabalho "honesto".

Os trabalhos encontrados, apesar das diferenças metodológicas e de interpretação, orientados por valores morais, religiosos e ideológicos, apresentaram uma conclusão comum: a de que não existe uma única causa para a mulher se prostituir, nem um único tipo de prostituição. Demonstraram, também, que ainda hoje essas mulheres continuam sendo vistas mais como "problemas" do que como pessoas merecedoras de atenção por parte do poder público cujas políticas deveriam contemplar o seu modo de vida. Como demonstra o fato de que após o fechamento da zona de prostituição confinada ${ }^{3}$, elas voltassem a ser lembradas pelo Estado somente com o advento da AIDS, como sendo um possível foco de transmissão da doença, como no passado ocorria com a sífilis.

\footnotetext{
${ }^{2}$ Monografias de conclusão do curso de teologia, de vários autores, encontradas na biblioteca da Casa de Convivência, e tônica presente nos artigos da revista "Mulher Libertação", publicação do Serviço a Mulher Marginalizada.

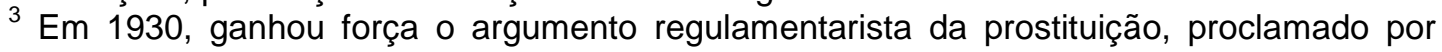
médicos sanitaristas que defendiam o discurso higienista do século XIX. Em 1940, foi fundada a "zona de prostituição confinada" com o objetivo de combater as doenças venéreas e o lenocínio. No ano de 1951, as autoridades acharam por bem desativá-la pelos mesmos motivos que os levaram a criá-la.
} 
Relativamente ao tema das drogas, a literatura consultada, dentre os quais citamos BIVAR et al. (1984); MACRAE (1994); ESCOHOTADO (1997), mostrou que nos anos 60 com o movimento hippie houve um incremento da contra-cultura iniciada uma década antes com a geração beat, que buscava novos valores em oposição aos da sociedade capitalista, em que o uso de drogas fazia parte de uma atitude contestatória que buscava além de tudo uma autonomia do homem com seu corpo, e relacionamentos que levassem em conta mais os sentimentos que as convenções sociais. Dessa forma, passaram a valorizar as experiências espirituais em oposição aos valores materiais vigentes.

Assim sendo, algumas substâncias como o LSD, Mescalina, Peiote, Cogumelos e Maconha, começaram a ser utilizadas com o objetivo de ampliação da consciência visando o auto-conhecimento .

Foi a partir dessa década, que a utilização de substâncias psicoativas, entrou para os temas de interesse da antropologia. Alguns estudos tornaram-se referência, como o de Castañeda sobre o uso do peiote e o de BECKER (1963) sobre o uso da maconha. Os usos eram estudados sob a perspectiva do uso ritual das plantas psicoativas por determinadas sociedades ou grupos, em que se observava que sua utilização no contexto de uma determinada cultura nunca extrapolava os limites dos valores culturais em que estavam inseridos, não ocasionando abusos ou problemas para os usuários e suas sociedades.

Nesse contexto, houve maior interesse no estudo do uso controlado dessas substâncias, tendo como pressuposto que, também nas sociedades complexas existiria um ritual de uso e iniciação em que ocorreria um aprendizado não só da maneira de usar, como também das sensações esperadas, dos locais para o uso, da dosagem adequada e de como evitar os efeitos indesejados, entre outros aspectos.

BECKER (1977), em seu artigo "Consciência, poder e efeito da droga", demonstrou como, tanto no uso das drogas lícitas como o das 
ilícitas, existe um conhecimento adquirido pelos usuários, mas ressaltou que, paradoxalmente, os usuários de drogas ilícitas têm mais conhecimentos e, portanto, mais poder sobre o seu uso e sobre a substância, pois que o responsável pela sua administração é ele mesmo e não um médico. Para o autor, esse conhecimento norteará a experiência que terá com a droga uma vez que os usuários já sabem que efeitos devem esperar, tanto no que se refere aos desejados como aos indesejados .

Cria-se então uma "cultura da droga" à medida que se conhece qual a melhor dosagem para obter os efeitos desejados, como se deve evitar os efeitos indesejados, qual a melhor via de administração, qual o melhor local para usá-la e com quem. Esse aprendizado é fruto de experiências do indivíduo que são "testadas" em comparação com as experiências dos demais. Dessa maneira, os efeitos que uma droga pode produzir, estão associados tanto à sua ação fisiológica, como às diferenças individuais e culturais, os cenários e o conhecimento circulante sobre a substância.

(....) Os índios e os caucasianos interpretam de maneira diferente as experiências com peiote e as "viagens" de LSD foram experimentadas como uma expansão da consciência, experiência religiosa transcendental, psicose ou "barato (BECKER 1977, p. 185).

ZIMBERG (1984), em seu livro "Drug, Set and Setting", discutiu sobre o uso controlado de substâncias psicoativas. Ele acompanhou usuários que mantinham um padrão de uso que resultava na redução dos efeitos indesejados. Verificou que eram pessoas com outras atividades, sendo que o uso de psicoativos ocupava apenas uma pequena parte de suas vidas.

O autor comentou que estudos da década de 60 igualaram o uso com o abuso e raramente deram atenção ao consumo ocasional ou moderado como padrão viável. Quando isso ocorria, eram vistos como um estágio transitório ou para abstinência ou para a utilização compulsiva, além do que só estudavam quem tinha problemas com o uso. Somente na década de 70 
a comunidade científica começou a reconhecer estudos sobre padrão de uso.

\subsection{Os usos da cocaína}

A história da cocaína é muito interessante para descrever o consumo e o contexto sociocultural, bem como as mudanças ocorridas nas vias e padrões de uso. A sua utilização, assim como das drogas de maneira geral, passa pela historicidade e reflexividade social de cada época. Ela vai da aceitação total por parte da sociedade - verdadeira panacéia, prescrita para os mais diversos males, símbolo de sucesso social, riqueza e status para quem consome - até a proscrição e repressão, gerando forte estigma aos consumidores (BUCHER 1992, DELPIROU e LABROUSSE 1988, ESCOHOTADO,1997).

A cocaína é um alcalóide (substância com propriedade de base capaz de reagir com ácidos como a cafeína e a nicotina) presente na planta Erythroxylon coca, nome científico da coca natural dos Andes onde era cultivada e utilizada pelos incas com caráter ritualístico. Era chamada de Mama Coca, usada em rituais de fertilidade e tida como uma dádiva dos deuses para fortalecer os "pobres mortais" (BUCHER, 1992).

Em 1860, o químico alemão Albert Niemann conseguiu isolar o seu alcalóide principal e o chamou de "cocaína". Em 1863, Ângelo Mariani, químico e comerciante da Córsega, lançou o vinho à base de coca (com uma concentração de 35 a 70 miligramas de cocaína por copo de vinho, o que corresponderia a uma "fileira" de coca), chamado "vinho Mariani", considerado um fortificante capaz de curar inúmeras doenças, foi um enorme sucesso na Europa; saudado por artistas, escritores, pintores, cientistas, reis e rainhas (como a rainha Vitória, o rei da Grécia, o czar da Rússia) e também pelo clero. O sucesso foi tanto que o papa Leão XIII condecorou Mariani com medalha de ouro. Ele não saía para seus retiros sem levar consigo o famoso vinho (DELPIROU e LABROUSSE 1988). 
“(....) O cardeal Lavigerie escreve: "Vossa coca da América dá aos meus padres europeus a força para civilizar a Ásia e a África” (DELPIROU e LABROUSSE 1988, p.41).

No ano de 1884, o jovem Sigmund Freud, após experimentar a cocaína - que era prescrita em formas de injeções subcutâneas e endovenosas - , passou a divulgar entusiasticamente seus efeitos e possibilidades de aplicação para os problemas de cansaço físico ou mental como estimulante; em psiquiatria, como antidepressivo para estados de depressão, inibição e melancolia; como afrodisíaco, na desintoxicação de morfinômanos e alcoolistas; como anestésico, em pequenas cirurgias de olhos, garganta e também em tratamentos dentários; entre outros usos. Freud prescreveu a cocaína ao seu amigo, o biólogo e físico Ernest Fleischl, para que se livrasse do uso da morfina, mas este apresentou uma psicose cocaínica que se somou à síndrome de abstinência à morfina, fato que levou Freud a deixar de prescrevê-la e de escrever sobre ela, mas não de usá-la. Ele só interrompeu o consumo em 1895 (Delpirou e Labrousse 1988).

Em 1886, em Atlanta, EUA, o químico John Styth Pemberton lançou o seu xarope à base de cocaína, cafeína e extratos da noz de cola, misturados com água e gás carbônico - a famosa Coca-Cola - que vai conservar sua formula original até 1903 , quando deixa de conter o extrato de cocaína.

Só a partir de 1890, a cocaína passou a ser aspirada, (até essa época ela era utilizada por via endovenosa, subcutânea ou oral); o costume era fazer duas "fileiras" por pessoa. Usada preferencialmente pelas elites, seu consumo também se dava em outras classes sociais, sendo este o consumo que causava maior apreensão, "(....) mas quem escandalizava eram os consumidores boêmios e lumpemproletários de diferentes índoles, e a entusiástica acolhida ao produto por parte dos negros" (ESCOHOTADO 1997, p.144).

Em 1898, Willstätter descobriu a fórmula exata de sua estrutura química. A partir de 1902, passou a ser produzida abundantemente por 
laboratórios farmacêuticos, sendo considerada um remédio milagroso servindo para curar os mais diversos males. Foi freqüentemente prescrita para o tratamento de dependências do ópio, da morfina e do álcool.

Em 1901, calcula-se que 30\% dos cocainômanos eram médicos ou dentistas.

Os casos de cocainomania aumentaram rapidamente, em função do consumo desenfreado, atingindo sobretudo as elites, as camadas "snob", alternativas ou marginais da alta sociedade e dos meios artísticos. A moda da cocaína conheceu o seu apogeu na década de 20 e no início dos anos 30. Lewin (1931), um dos primeiros críticos de Freud, constata que membros de todos os círculos profissionais estão envolvidos, desde médicos e políticos até prostitutas e bandidos (BUCHER 1992, p.121-122).

A cocaína era também conhecida como droga da moda para vencedores. No ano de 1914, os Estados Unidos proibiram o uso da cocaína. A partir daí, ela deixou de ser a droga da moda por aproximadamente 4 décadas, em função não só de sua proibição, mas também pela entrada no mercado das anfetaminas, estimulantes mais baratos e muito mais potentes (ESCOHOTADO 1997).

Nos anos 60, com a restrição à circulação das anfetaminas, a cocaína voltou a ocupar o seu posto. Em meados dos anos 80, passou a ser conhecida como a droga da produtividade e associada aos yuppies, (denominação que se deu aos jovens executivos de sucesso) (BUCHER 1992).

Segundo (BUCHER 1992) a cocaína é um estimulante potente do sistema nervoso central, deixando-o em estado de alerta. Os efeitos descritos são maior lucidez e concentração, eliminação do cansaço, sensação de bem-estar e euforia, desinibição e maior sociabilidade. $O$ relato 
de Freud, em 1884, citado por ESCOHOTADO (1997), descrevia estas sensações:

O efeito consiste em otimismo e uma duradoura euforia que não se diferencia da normal em uma pessoa saudável. Percebe-se um aumento do autocontrole, a pessoa adquire um grande vigor e é capaz de trabalhar (....) O melhor uso se faz com a administração de doses pequenas mas eficazes, repetidas freqüentemente para a manutenção dos efeitos (....) A cocaína é um estimulante muito mais vigoroso e menos daninho que o álcool (ESCOHOTADO 1997, p.148).

Para se obter a pasta-base de coca procede-se ao maceramento das folhas da planta com querosene, e depois de seca, macerada nova0ente , $\square \square a ́ c i d o ~ s u l f u ́ r ~ \square c o$ diluído. Para transformá-la em cocaína, necessita-se de purificá-la o que é conseguido em lavagens com éter, ácido clorídrico e acetona. O crack é feito da pasta-base - sem purificação-com bicarbonato de sódio e água formando cristais que recebem o nome de "pedras". Também pode ser conseguido a partir do pó de cocaína, adicionando água e bicarbonato e aquecendo-o. O nome crack deve-se ao ruído que as "pedras" emitem quando são aquecidas pelo fogo (ESCOHOTADO 1995).

\section{A entrada do crack no cenário mundial}

Como se sabe, a repressão às drogas faz aumentar seu preço no mercado; dentro dessa lógica, uma das explicações dadas para o aparecimento do crack foi a intensificação da repressão aos laboratórios de refino de cocaína feito pelos EUA, em meados dos anos 80, favorecendo o seu surgimento, como comentaram UCHÔA (1996) e ESCOHOTADO (1997).

O crack teria surgido no momento de maior pressão da polícia e de maior dificuldade para exportar a massa, por exemplo para o México e Peru. A solução foi "trabalhar a 
massa" que estava parada para não perder dinheiro. Assim, a criação do crack teria sido motivada por esses fatores: grande quantidade de pasta-base e dificuldade de mandá-la para o refino, trabalho que necessita de estrutura especializada (UCHÔA 1996, p.37).

No caso do crack (....) Sem dúvida, o controle sobre os precursores da cocaína (éter e acetona, sobretudo) foi o fator determinante para que produtores peruanos, bolivianos e colombianos começassem a exportar pasta-base ao invés de cloridato. A malícia do mercado negro fez o resto (ESCOHOTADO 1997, p.157-158).

O crack marca sua entrada nos EUA em 1981 em Los Angeles. E se estabelece através das áreas degradadas das grandes cidades, de alta densidade de população negra e hispânica, como, por exemplo, os bairros novaiorquinos do Bronx e Harlem em 1984 (DELPIROU e LABROUSSE, 1988).

A presença do crack no Brasil é um tanto nebulosa. As informações mais conhecidas foram divulgadas em jornais e revistas baseadas em dados policiais. Estas situam sua entrada, no país, no ano de 1988, no estado de São Paulo através das "bocadas", (gíria que se refere aos pontos de venda), da periferia do município de São Paulo, mais precisamente nos bairros de São Mateus, Cidade Tiradentes e Itaquera, situados na região leste da cidade (UCHÔA 1996).

Segundo pesquisa jornalística desenvolvida por UCHÔA (1996), O crack começou a ser procurado mais intensamente por usuários, nas ruas da região da Luz, no ano de 1991, mas também não se sabe ao certo quando entrou nessa parte da cidade.

A estratégia utilizada pelos traficantes para atrair os consumidores de cocaína para o consumo do crack foi o de passar a só vender a pedra em 
vez do pó. Outro fator que ajudou a sua entrada foi o preço que, inicialmente, é menor do que o da coca e seu efeito mais intenso, porém menos duradouro fazendo com que se repita várias vezes o seu uso para conseguir o mesmo efeito, o que encarece a sua manutenção com o passar do tempo dando, portanto, mais lucro para o tráfico (UCHÔA 1996).

O crack é um negócio muito mais rendoso do que a cocaína, pois um quilo de cocaína que custa em torno de US $\$ 10$ mil e pode ser convertido em dez mil porções de crack com retorno de US\$250 mil. Em São Paulo, segundo dados do Departamento Estadual de Investigações sobre Narcóticos da Polícia Civil (DENARC), estima-se que o mercado do crack movimente diariamente cerca de $\mathrm{R} \$ 5$ milhões (UCHÔA 1996).

Dados divulgados pela polícia em um caderno especial sobre drogas do Jornal o "Estado de São Paulo", de 19/09/99, informavam que a cocaína movimenta, no mundo, aproximadamente US\$ 120 bilhões; o Brasil, as autoridades não divulgam as cifras para não estimular o comércio. Dados do DENARC, publicados no mesmo jornal, em 29/9/99, informavam sobre a apreensão de $6 \mathrm{~kg}$ de pasta base custando $\mathrm{R} \$ 5.000,00$ por $\mathrm{kg}$. Essa quantidade daria para fazer 15 mil pedras de crack que geraria um lucro de aproximadamente $R \$ 150.000,00$, visto que o preço médio estava em torno de $R \$ 10,00$. Se pensarmos que a quantidade que entra no país é muito maior que essa dá para termos uma noção do volume de dinheiro que circula no comércio de cocaína/crack.

Este mesmo texto jornalístico também dava informações sobre a origem e qualidade da droga que entra no país. Quase toda a pasta-base era proveniente da Bolívia e se destinava às cidades de São Paulo e Rio de Janeiro. Segundo os especialistas esta pasta era a de pior qualidade, pois já viria adulterada, com vários produtos químicos como derivados benzênicos e solventes orgânicos, entre outros, deixando-a com 30\% de pureza. Ao chegar em São Paulo, seria novamente misturada com soda cáustica, solução de bateria de carro, água sanitária, cimento e hormônio para a engorda de gado. 
O crack na região central de São Paulo se apresenta da seguinte forma, segundo relatos:

A pedra

"Pedra" é a forma como o crack é vendido e utilizado. O seu preço varia de acordo com o tamanho e pureza. Tem "pedras" de $R \$ 5,00$, de $R \$$ 10,00 , de $R \$ 20,00$ e farelos de pedra a $R \$ 1,00$.

O tráfico

O tráfico de crack na região da Luz é muito pulverizado, e sua distribuição parece ter a seguinte ordem: os hotéis que têm maior quantidade, fazem chegar às ruas, por intermédio de homens (geralmente) mais diretamente ligados aos locais de distribuição, que passam para mulheres, homens, crianças e jovens que vivem pelas ruas; estes, por sua vez, ficam com uma parte para uso próprio e vendem o restante para outros usuários que vivem ou freqüentam a região.

Não existe distinção, para ser traficante de crack, segundo sexo ou idade. Geralmente o usuário do crack é responsável pelo tráfico, pois dessa forma garante o próprio consumo.

O uso

Usa-se o crack da seguinte forma: fuma-se um cigarro e as cinzas destes vão sendo colocadas no cachimbo, geralmente feito de antenas de carro; por cima das cinzas é colocada a pedra e então acende-se com o isqueiro que deve estar sempre à mão. Traga-se a fumaça segurando-a por um tempo alcançando-se, assim, o efeito desejado. Os usuários costumam fumar agachados ou sentados no chão. As mulheres relatam fumar de $10 \mathrm{a}$ 15 pedras médias por dia, mas muitos usuários usam quantidades maiores. A expressão mais usada é fumar em vez de "pipar" (gíria utilizada para o ato de fumar o crack).

Locais de uso 
O crack foi usado por toda a região da Luz, desde aproximadamente 1991 , inclusive nos hotéis que traficam e alugam quartos ao preço de $R \$$ 5,00 para quem quiser fumar ou "fazer programas"4. Há 2 anos, os usuários se concentravam nas calçadas das ruas: Protestantes, Gusmões, Triunfo, Gal. Couto de Magalhães, mas depois da operação policial "Tolerância Zero", espalharam-se por toda a região da Luz.

É importante observar que com a entrada do crack, ao contrário da cocaína aspirada, que teve inúmeros surtos de uso no início do século, tanto no Brasil como em outros países, cujo consumo era conhecido como um "vício elegante" ligado às pessoas de prestígio, o crack se caracteriza por seu uso estar mais associado às pessoas de baixo poder aquisitivo, ou seja, os excluídos socialmente. "(....) o crack representa uma mística da miséria; se a cocaína simboliza o luxo dos ricos e vencedores, a base bicarbonatada de coca simboliza o luxo dos miseráveis" (ESCOHOTADO 1997, p. 157).

O crack, desde o seu surgimento, ficou conhecido como a "droga das ruas", mais barato do que a cocaína, proporcionava aos pobres o acesso mais fácil ao prazer caro das elites. Embora mais barato, torna-se de difícil manutenção, pois seus efeitos são mais potentes, mas muito menos duradouros.

Este fato contribui para a dinâmica de sua circulação nas ruas, pois o consumidor, não podendo sustentar o seu consumo, termina por realizar um pequeno tráfico criando-se, assim, uma grande rede de pequenos traficantes pelas ruas, o que configura o tráfico pulverizado que é um diferencial do crack em relação à cocaína. Essa situação é observada nas ruas de São

\footnotetext{
${ }^{4} \mathrm{O}$ termo "programa" será utilizado no texto, por ser esta a designação que as mulheres da Luz dão à forma como ganham dinheiro. É importante observar que não se autodenominam de profissionais do sexo, que poderia denotar algum grau de organização, mas também não se referem como prostitutas, a não ser quando querem se desqualificar; talvez seja uma defesa da desqualificação externa percebida.
} 
Paulo, especificamente na região em que se desenvolveu a pesquisa, chamada de Crackolândia ${ }^{5}$, no bairro da Luz.

Nota-se, pelas descrições anteriores e pela observação da questão na atualidade, que o estigma associado aos consumidores, se não é exclusividade das pessoas pobres e já rotuladas como "desviantes", é nelas que vai se fixar, levando o seu consumo a ser pensado como um caso de polícia por oferecer risco social.

\subsection{A relação entre prostituição, uso e tráfico de drogas.}

A relação entre prostituição, uso e tráfico de drogas não se constitui em fenômeno recente. FONSECA (1982), autor que fez levantamento histórico minucioso tanto da prostituição como do tema das drogas, em seu trabalho "Submundo dos tóxicos em São Paulo", deixa claro como as duas práticas são tratadas. Na leitura de seu texto, nota-se que este autor toma esses comportamentos como "desviantes" e de fácil associação relatando, ainda, que no início do século, as prostitutas figuravam nas estatísticas de infrações criminais pelo uso e tráfico de drogas.

Segundo ele, esse problema atingiu maiores proporções nos anos 20, muito embora antes dessa época, o éter, a cocaína, a morfina, o ópio e a maconha fossem usados em São Paulo. $O$ autor relatou que um delegado da Polícia, em 1918, alertava para esse problema em um relatório, no qual falava dos "vícios elegantes", que tinham essa denominação por serem consumidos nas "Pensões Chics" e "Pensões Alegres", casas de prostituição freqüentadas por homens de maior poder aquisitivo e prestígio. Embora nas zonas de baixa prostituição ${ }^{6}$ existisse o mesmo problema, o que mais preocupava as autoridades eram os locais que tinham a freqüência de jovens da alta sociedade.

\footnotetext{
${ }^{5}$ Gíria que indica a existência de grande circulação de crack na região, e utilizada pelos usuários, autoridades policiais, profissionais de saúde pela mídia e a população em geral. ${ }^{6} \mathrm{O}$ termo baixa prostituição empregado por FONSECA (1982) refere-se a mulheres oriundas de extratos de baixo poder aquisitivo, e que na prostituição atendiam o mesmo segmento populacional. Perspectiva adotada no presente estudo.
} 
De acordo com o autor, o número de cocainômanos aumentava, tornando-se um fato preocupante para as autoridades locais, principalmente como foi dito anteriormente, devido a sua disseminação nas altas rodas; era um "vício chic", uma "moda elegante", e por isso mesmo dificultava a ação policial. A organização do tráfico se dava em locais bem freqüentados, como os clubes de danças, cabarés, "pensões chics" e casas de jogos onde se encontrava a alta prostituição e os moços das altas rodas (jovens de famílias abastadas e influentes) da época. FONSECA (1982) descreveu uma diligência policial em um desses locais, o "Cabaret Imperial Dancing", onde foram presos traficantes, e, entre eles, duas prostitutas apontadas de iniciação de muitos jovens no "vício da cocaína".

O autor utiliza jornais da época, em que figuram a prisão de outras prostitutas, presas comprando cocaína e cita que o vício da cocaína também se espalhava pelo baixo meretrício situado à rua Cruz Branca, e que era abastecido por uma farmácia da rua do Gasômetro no Brás.

Conforme exposto anteriormente, a relação prostituição e drogas não se constitui em um fenômeno recente, porém, com o advento do crack, acreditamos que ocorreu uma deterioração da qualidade de vida das mulheres que se tornaram consumidoras deste tipo de droga.

A discussão sobre uso de crack não consegue ficar isenta do caráter sensacionalista que cerca o debate sobre o uso de drogas de uma maneira geral. Dessa forma, corre-se o risco de ver o problema com proporções maiores do que as reais, dificultando a busca de alternativas para lidar com a situação. A maioria dos estudos nessa área tentam traçar um perfil epidemiológico desse uso - que é importante - mas não é capaz de dar conta de todos os fatores envolvidos nessa questão por não contextualizarem esse consumo.

Com freqüência são feitas generalizações percebendo-se o fenômeno do consumo de drogas como sendo homogêneo para todos os que participam dessa prática enfatizando, assim, a questão em torno da 
substância como se o indivíduo não tivesse nenhuma participação na sua busca, nas formas de sua utilização e nos significados atribuídos a esse uso. Isso deve-se, em parte, ao modelo médico-higienista na forma de abordar esta problemática,“(....) este modelo não leva em conta as razões pelas quais se procura drogas. Entre estas, destaca-se a obtenção de prazer anseio que, com certeza, não é condenável em si “ (BUCHER 1992:146). Nessa ótica, a droga ou é vista como um problema de ordem médicopsiquiátrica ou como caso de polícia muito embora, a própria história, no caso da cocaína, demonstre como esta adquiriu diferentes usos, passando de um uso ritual e controlado para um uso político; uso médico e recreacional e de interesse mercadológico para posterior repressão.

É interessante observar que a cocaína se configura como a droga da modernidade, propícia ao estilo de vida das grandes metrópoles, como descreveu BUCHER (1992):

(....) a cocaína é um estimulante poderoso que deixa o sistema nervoso central em estado de alerta, comparável com um estado de alta-tensão - em oposição ao stress da vida cotidiana, comparável a um estado de baixa-tensão, desarmando o indivíduo e inibindo uma série de iniciativas das quais dependem o seu desempenho, o seu sucesso, a sua carreira (p.116).

Cabe ressaltar que a relação drogas-prostituição, mais que uma união fácil, do ponto de vista da moral vigente em que a rotulação de comportamentos tidos como "desviantes" é prática corrente, é uma relação que envolve temas tabus da sociedade que vão desde a questão da sexualidade, do prazer até a da autonomia do ser humano sobre e com seu corpo. Provavelmente por este motivo resulte em tanta polêmica. 


\subsection{Histórico da prostituição na região da Luz}

Com relação a localização dos "pontos" de prostituição na cidade de São Paulo, podemos destacar que a figura da prostituta sempre esteve presente na região central da cidade, tendo as ruas comerciais como espaço privilegiado para a exposição de sua "mercadoria". Em seu levantamento, FONSECA (1982) descreveu quais eram essas ruas.

Segundo o autor, o núcleo principal da prostituição, por volta 1885 , localizava-se nas ruas: da Esperança. do quartel, Senador Feijó, São João, Largo do Paissandú, São José (hoje Libero Badaró), Becos dos Trens e dos Mosquitos. E também na rua Cruz Branca (Brás) e próximo à hospedaria dos Imigrantes.

As ruas da Esperança, do Quartel, Beco dos Trens e dos Mosquitos desapareceram se transformando no que seria hoje a praça da Sé. A rua da Esperança e o Beco dos Mosquitos, juntamente com o bairro do Brás reunia o baixo meretrício, que eram mulheres mais escandalosas sem muito asseio que andavam freqüentemente com poucas roupas e embriagadas provocando muitas brigas. A rua São João e o Largo do Paissandú reunia o mais alto meretrício da época.

Em 1911, com o desenvolvimento urbano, houve um alargamento da antiga Praça da Sé e, posteriormente, o alargamento da rua Senador Feijó, levando as prostitutas a serem desalojadas dessas áreas e das áreas vizinhas. Assim, concentraram-se nas ruas dos Timbiras, Amador Bueno, Ipiranga e imediações. Após a revolução de 1930, a polícia as expulsou das proximidades da Avenida São João, elas então espalharam-se por toda a cidade causando protestos dos moradores. Com isso, houve permissão para que voltassem aos antigos lugares, mas não se conseguiu o retorno de todas, pois muitas delas permaneceram nas várias regiões da cidade (FELDMAN 1988). 
Segundo FONSECA (1982) decidiu-se então por escolher uma região da cidade para que ficassem dessa forma circunscritas, facilitando assim a inspeção policial e sanitária por parte das autoridades, e evitando o constrangimento das famílias. Isso não foi tarefa fácil pois ninguém as queria por perto.

As autoridades passaram a determinar os locais onde as mulheres prostitutas não poderiam se fixar que eram próximos a escolas, igrejas, fábricas, centros residenciais e estradas de ferro.

Em 1940 chegam a uma conclusão e decidem-se por fixá-las no bairro do Bom Retiro, nas ruas: Itaboca, Aimorés, Carmo Cintra e parte da Ribeiro de Lima. Essas ruas passaram a ter uma movimentação até então desconhecida para aquela região, principalmente no período noturno, quando vários homens vindos dos mais diferentes bairros circulavam em busca das prostitutas, o que veio ocasionar problemas não previstos quando da mudança. Como diria FONSECA (1982): "Era o começo da sujeira que viria a ser uma das características daquelas vias públicas.” (p.210)

Em 1951, as autoridades resolveram desativar a zona de prostituição confinada com o objetivo de combatê-la e, assim, o lenocínio e as doenças venéreas. Em 1952 foi oficialmente desativada, levando as prostitutas ao protesto nas ruas causando distúrbios e quebra-quebras. A partir de então, muitas delas permaneceram no bairro do Bom Retiro, passaram a fazer "ponto" na Estação da Luz, Parque da Luz e imediações.

Atualmente, as que ficam nas imediações da estação da Luz, principalmente as das ruas Dos Protestantes, Do Triunfo e Dos Gusmões, região conhecida como a Crackolândia pesa também a relação entre o uso e o tráfico do crack, mas tal fato parece não preocupar a Delegacia de Narcóticos, que fica próxima, talvez porque a eles não interessa o tráfico no varejo, como parece ocorrer com o crack naquela região. 


\subsection{Espaço Urbano}

O espaço urbano, do ponto de vista sociológico, não deve ser encarado como simples espaço geográfico, mas, antes de tudo, como um espaço relacional onde se constróem relações de amizade, lazer, trabalho e identidade. Essa relação pode ser construída por associação ou oposição levando ao reconhecimento como sendo o nosso (pedaço) ${ }^{7}$ ou como o pedaço do outro que devemos circular com cuidado até conhecermos bem as regras. Assim, alguns locais da cidade terminam por ser identificados pelas práticas que lá se desenvolvem, sendo estas formais ou informais.

Dessa maneira, as cidades se organizam constituindo locais que se especializam nas mais variadas formas de atividades, como por exemplo o comércio e o lazer, que MAGNANI (1996) chamou de "manchas"8 no espaço urbano. Também é comum a toda cidade ter um espaço reconhecido como local de prostituição.

Para PARK (1987) isto seria produto não só de uma organização administrativa da cidade, - tais locais estariam longe dos espaços de moradia e de trabalho produtivo e sempre próximos às áreas de lazer e de serviços - como de uma organização mental que a cidade produz. Esses espaços se configurariam em uma "região moral", local onde "os impulsos, as paixões e os ideais vagos e reprimidos se emancipam da ordem moral dominante." (p.64)

\footnotetext{
${ }^{7}$ Magnani (1996:39) explica que a categoria, pedaço, no contexto do bairro "tem como referência a articulação de vínculos já existentes - de família, vizinhança, procedência resultando na sociabilidade típica do pedaço", e no contexto de áreas usadas principalmente como "ponto" de encontros e de lazer, a categoria pedaço tem o espaço como referência em que os freqüentadores se reconhecem como portadores dos mesmos símbolos, valores e gostos e manejam os mesmos códigos, portanto, se reconhecem como iguais.

"Magnani (1996) sobre a categoria "mancha" diz que ela, ao contrário da categoria "pedaço", está "sempre aglutinada em torno de um ou mais estabelecimentos, apresenta uma implantação mais estável tanto na paisagem como no imaginário. As atividades que oferece e as práticas que propicia são o resultado de uma multiplicidade de relações entre seus equipamentos, edificações e vias de acesso - o que garante uma maior continuidade, transformando-a, assim, em "ponto" de referência físico, visível e público para um número amplo de usuários." (p.42)
} 
Estes locais, muito embora à primeira vista pareçam ter sido constituídos de maneira informal, um olhar mais atento sobre a sua história descobrirá que os projetos de urbanização e as políticas públicas, de uma maneira geral, exerceram papel importantíssimo em sua constituição, fixação e deslocamento.

A história da prostituição no centro da cidade de São Paulo demonstra isso muito bem. Se no passado, o plano de inscrever a cidade no mundo moderno e civilizado redesenhou o seu traçado e sua fisionomia, bem como, ditou novos comportamentos, também determinou a revalorização de diversos locais com a conseqüente expulsão de seus antigos freqüentadores, que passaram a ser considerados indesejáveis. CARNEIRO (1993), em sua dissertação de mestrado intitulada: "A Vertigem dos Venenos Elegantes", transcreveu trecho de um artigo do jornal "Comércio de São Paulo", de 13 de dezembro de 1911, onde a inauguração do Teatro Municipal foi tomada como símbolo do processo "civilizatório".

O magnífico monumento eleva-se majestoso, (....) São Paulo, cujo elemento de prosperidade está na corrente migratória, como fim de alcance econômico e civilizador deve colocar-se a par dos centros populosos adiantados, no que eles tem de atrativos e conforto moral para melhor vantagem oferecer não só do próprio colono como do viajante em geral.(....) O Teatro é um mostruário de civilização: este aqui fica e, da nossa dirá!.(1993, p.2)

(....) Há oito dias que só ouço falar no Municipal, nos gastos que o Municipal motiva, (....) enquanto o povo, aquele que certamente não comparecerá senão da rua, para e admira o belo monumento, cuja fachada lateral lembra a principal do Trocadero, tal sua admirável situação.(Jornal Comércio de São Paulo, 10/09/91, citado em Carneiro, 1993, p.9) 
A autora descreve como esse processo civilizatório e emancipador, que buscava as luzes do progresso, estava embasado em um racionalismo científico, investindo o saber médico de poder saneador. Uma das tarefas civilizadoras era a de erradicação de doenças (epidemias de febre amarela e de cólera no Estado, escarlatina e tifo na capital), que paradoxalmente o próprio progresso implementou, visto o grande afluxo de imigrantes que acorria à capital paulista. Coube à medicina se manter atualizada com as práticas terapêuticas dos grandes centros urbanos utilizando "venenos" cada vez mais potentes.

Com isso, o discurso higienista do século XIX ganhou força como discurso normatizador da ordem (e da prática médica), por definir as práticas saudáveis e que não acarretassem risco para a saúde dos cidadãos.

Como para algumas práticas, tidas como inadequadas, não existissem leis que as proibissem, como no caso do uso dos "venenos elegantes" e da prostituição, cabia à ordem médica estabelecer controle.

Morfina, cocaína, ópio e éter, (....)pertenciam à classe dos venenos ou tóxicos,(....). Quando indevidamente usados, em doses muito elevadas, poderiam trazer a morte e, em menores doses, uma embriaguez especial. A finalidade destas substâncias era terapêutica, destinadas a combater a dor e outros sintomas de doenças, como náuseas, diarréia, tosse e neurastenia. Eram medicamentos, cuja venda, efetuada exclusivamente pelas farmácias, era sujeita à fiscalização, como qualquer veneno. Para evitar o emprego de doses inadequadas, o acesso a eles só era facultado mediante prescrição médica orientando sua utilização (CARNEIRO 1993, p.38).

Mas, a elite paulista no desejo de tornar-se cosmopolita, buscava copiar, não só os desenhos da cidade, como os hábitos e costumes da 
"Europa civilizada". Entre esses hábitos o de consumir os "venenos elegantes" como eram chamadas as substâncias psicotrópicas.

Paulatinamente, o consumo lúdico desses remédios narcóticos, foi se difundindo pelos centros urbanos brasileiros, acompanhando a tendência, existente desde o século passado, de sua expansão pelas populações das cidades do mundo ligadas a influências cosmopolitas (CARNEIRO 1993, p.43).

No caso da prostituição, o discurso médico passou a defender o controle sanitário da prática visando deter a disseminação das doenças sexualmente transmissíveis. Como a mulher era vista como foco transmissor o que ocorreu é que o controle ficou centralizado na figura da prostituta. Uma das propostas foi a de mantê-las nas "casas de tolerância" uma vez que na nova ordem, cada um deveria estar em seu lugar, como discutiu FELDMAN (1988) em sua dissertação de mestrado "Segregações espaciais urbanas. A territorialização da prostituição feminina em São Paulo".

A cidade, produto do crescimento do aparelho produtivo, do aumento de rentabilidade e de população é, segundo os higienistas, o local onde se concretiza o perigo decorrente da cohabitação numerosa e de contatos desregulados. Os médicos propõem não apenas a transformação fisionômica da cidade - alargamento das ruas, abertura de praças, construção de esgotos, etc. - como também determinam a localização espacial e as formas de contato da população: a meta é a ordem, transformando "as multidões confusas, inúteis ou perigosas, em multiplicidades organizadas (Foucault 1975, citado por FELDMAN 1998, p.40).

A prostituição era vista como um dos elementos de desordem urbana sendo necessário sua organização e delimitação de seu espaço de 
circulação. À mulher prostituta imputava-se também a responsabilidade na iniciação dos jovens de "boa família" no uso de drogas.

A mulher prostituta é o contraponto à figura da mulher/mãe/esposa esteio da família, representação ideal feminina elaborada pelos médicos e conveniente à nova ordem econômica. Se à segunda se destina o espaço doméstico, onde as funções de esposa e mãe devem obedecer a um modelo constituído pelo amor aos filhos, submissão econômica e intelectual ao marido e sexualidade circunscrita à zona de controle da mãe, à mulher prostituta se destina o espaço da casa de tolerância (FELDMAN 1998, p.41).

Tais casas deviam se estabelecer longe das famílias, e conter suas ocupantes fora dos espaços públicos. As autoras (CARNEIRO 1993; FELDMAN 1998) discutiram em seus trabalhos que abrangem o início do século $\mathrm{XX}$, como o almejado progresso modificará não só 0 aspecto geográfico da cidade, como determinará novas regras de circulação e apropriação dos espaços públicos. Onde, em nome do processo "civilizatório e organizativo", criaram-se espaços de segregação, como foi o caso da zona de prostituição confinada.

Apontaram também para o paradoxo que a nova ordem econômica criava, como no caso do uso dos "narcóticos" para combater os mais diversos males termina por fugir ao controle da ordem médica, com a industria do mundo civilizado despejando no mercado quantidades maiores do que o consumo médico prescrevia.

Atualmente a história parece se repetir, pois existe uma política em curso visando revitalizar o centro da cidade, com projetos de restauração de espaços históricos com sua utilização para fins culturais, com certeza mais nobres que no passado, como é o caso do antigo prédio do Departamento de Ordem Política e Social (DOPS). 
A "melhor sala de concertos do mundo" foi instalada em um espaço da estação Júlio Prestes, após sua restauração. A Pinacoteca do Estado foi restaurada e recentemente o Parque da Luz vem passando por reformas e foi incorporado a Pinacoteca para exposições ao ar livre, o que fará possivelmente, com que se cobre ingresso aos freqüentadores.

Discute-se, ainda, a construção do maior prédio do mundo na região do Parque D. Pedro. Todas essas modificações estão sendo incrementadas através da Associação Viva o Centro, que tem como objetivo a revalorização do espaço histórico/urbano da região central, a centralização administrativa da cidade e também do Estado (propõem a volta do Governo) para a região central. Seus principais mantenedores são instituições financeiras. Segue abaixo descrição de seus objetivos e alguns de seus princípios.

A associação objetiva o desenvolvimento da Área Central se São Paulo, em seus aspectos urbanísticos, culturais, funcionais, sociais e econômicos, de forma a transformá-la num grande, forte e eficiente Centro Metropolitano, que contribua eficazmente para o equilíbrio econômico e social da metrópole e para o pleno acesso à cidadania e ao bemestar de toda a população.

A Associação Viva o Centro defende como princípios que:

A identidade da metrópole resulta do processo pelo qual os valores do seu patrimônio histórico, arquitetônico, cultural e econômico são percebidos e apropriados por seus cidadãos;

O Centro metropolitano é o local por excelência onde investimentos públicos e privados devem complementar-se em benefício de um harmônico desenvolvimento urbano, social, cultural e econômico da metrópole.

Nesta política de revalorização, a expulsão dos antigos freqüentadores da região - camelôs, mulheres que fazem programa, crianças 
e jovens em trânsito para rua, consumidores/traficantes de drogas - parece ser a tônica atraindo, assim, futuros investidores para se fixar na área e expulsando os "indesejáveis" ou melhor as "classes perigosas" como no passado.

Em que pese as semelhanças entre o passado e o presente da região e seus atores, nota-se a necessidade de enfatizar que existe uma apropriação do espaço urbano por parte destes, visto ser um local conveniente para o desenvolvimento de suas práticas, por acontecer grande circulação de pessoas. Deve-se então relativizar o peso da constituição deste espaço sobre os atores e suas práticas.

Portanto, não se pode conhecer os atores sociais que circulam na região da Luz, entender as relações que travam e as atividades que desenvolvem sem pensar no espaço urbano em que estão inseridos. Como espaço entende-se, local de sociabilidade, ou seja, lugar privilegiado onde se constróem redes de sociabilidade e identificação com estilos de vida.

No texto, "Crianças e jovens em trânsito para a rua", ADORNO (1996) discutiu a questão do espaço como local de construção social de identidades e padrões de sociabilidade

Nesse sentido, ao definir "crianças e jovens em trânsito e em direção à rua, falamos de experiências de vida, de "estilo de vida", marcados e construídos por adesão a um espaço, que por ser amplo, exposto, desprotegido e alvo de assédios; requer a construção de estratégias, de mecanismos de manipulação e defesa que acabam por formar um tipo de sociabilidade que se produz e reproduz tendo como referência o grupo, "a turma", o "bando", que se opõe à casa, à família, como forma de organização de vida (ADORNO 1996, p.4). 
Analisando a região da Luz, através de sua história, nota-se que esta sempre foi um espaço de passagem, de possibilidade de acesso a locais mais desejados. Utilizando-se a categoria de pórtico, descrita por MAGNANI (1996) conseguimos pensá-la melhor. Por pórtico entende-se uma região sem uma identidade marcada, como descreveu o autor:

Trata-se de espaços, marcos e vazios na paisagem urbana que configuram passagens.(....) Terra de ninguém, lugar do perigo, preferido por figuras liminares e para a realização de rituais mágicos - muitas vezes lugares sombrios que é preciso cruzar rapidamente, sem olhar para os lados... (p.45)

Para entender qual a lógica e os códigos que regem esse espaço, que sempre abrigou o que era considerado indesejável social e moralmente, o conceito de liminaridade é um conceito operativo que facilita tal compreensão.

A liminaridade faz parte de um processo ritual em que a pessoa está deixando de fazer parte de um grupo, mas ainda não está integrado a outro; nesta fase o sujeito liminar é ambíguo. Como citou TURNER (1974):

As entidades liminares não se situam aqui nem lá; estão no meio e entre as posições atribuídas e ordenadas pela lei, pelos costumes, convenções e cerimonial. (....) Assim, a liminaridade freqüentemente é comparada à morte, ao estar no útero, à invisibilidade, à escuridão, à bissexualidade, às regiões selvagens e a um eclipse do sol ou da lua. (p.117)

Os sujeitos liminares se agrupam em comunitas em que os individuos se organizam em torno de suas necessidades reais e rituais.

$O$ (....) que surge de maneira evidente no período liminar, é o da sociedade considerada como um "comitatus" nãoestruturado, ou rudimentarmente estruturado e relativamente indiferenciado, uma comunidade, ou mesmo comunhão, de 
indivíduos iguais que se submetem em conjunto à autoridade geral dos anciãos rituais (TURNER 1974, p.119).

Em um espaço de liminaridade deve-se ficar alerta. Não é um local para quem não conhece os códigos. O crack, neste sentido, possibilita este estado, além da sensação de "estar legal" e de ser "capaz de fazer qualquer coisa". Ao usá-lo, diferencia-se do sentimento de exclusão que já incorporaram e se igualam a outros sujeitos liminares, pois só se pode ficar ali se for um igual. Viver neste espaço é viver a ritualização de sua exclusão ou atribuir um valor diferencial da situação inicial de exclusão, como se adquirisse certa autonomia sobre ela, pois se organizando no espaço liminar cria-se possibilidades de manipulação dessa identidade com objetivo de conseguir alguns ganhos dos demais atores sociais, seja pelo medo, pela comiseração ou solidariedade. 


\section{METODOLOGIA}

Pretende-se nesta parte do estudo, discutir algumas questões referentes à opção teórico-metodológica que norteou a realização desta pesquisa. A opção pela região da Luz, deve-se principalmente pelo fato de integrar a área conhecida e referida como Crackolândia, tanto por seus freqüentadores como pelas autoridades policiais, sanitárias e também pela mídia.

O reconhecimento do local, por uma das práticas que lá ocorrem, demonstra uma reflexividade social, e uma rotulação das pessoas que ali circulam.

Devido à própria natureza do objeto a ser estudado, optou-se por uma metodologia qualitativa. Esclarece-se que a utilização desse tipo de abordagem não visa estabelecer oposição ou crítica à metodologia quantitativa. $O$ debate entre quantitativo versus qualitativo foi exposto por MINAYO (1993) em seu livro "O desafio do conhecimento", no qual a autora discutiu a forma inadequada do encaminhamento deste debate no campo da pesquisa social.

Segundo a autora, o estabelecimento desta dicotomia refletirá em pesquisas nas quais os números não representam a realidade social, por outro lado encontraremos trabalhos imersos em subjetivismo ocultando facetas da realidade. Diante deste impasse, sugere o aproveitamento de ambas metodologias sem esbarrarmos em reducionismo.

Encontra-se ainda sobre este tema, a proposta de triangulação em que a utilização da metodologia qualitativa não representa oposição aos dados quantitativos. Cabe ainda destacar a importância da sensibilidade do pesquisador no que se refere à questão do método, na área da Saúde Pública, bem como em outras áreas do conhecimento, diante dos novos problemas colocados pela sociedade atual (ADORNO et al, 1994). 
BECKER (1997) defendeu a idéia de que a metodologia não pode ser pensada "a priori" e sim como conseqüência do próprio objeto de estudo e das relações que se estabelecem no campo da pesquisa. Portanto, tem de ser pensada por quem está fazendo a pesquisa. Defende ainda, que a interação pesquisador, contexto e pesquisado fazem parte do método devendo também fazer parte da análise.

(....) mas a análise não deve confiar apenas na lógica da análise de variáveis ou na teoria da probabilidade e abordagens similares. Deve, ao invés disso, incorporar as descobertas da própria sociologia, tornando os aspectos sociológicos e interacionais do método parte do material submetido à revisão analítica e lógica (BECKER 1997, p.28).

Neste estudo, utilizou-se da contribuição da antropologia, mais especificamente da etnografia. Para GEERTZ (1989), o que se faz em antropologia é sempre uma etnografia e só com base no entendimento do que seja a prática etnográfica é que se compreende o que é a análise antropológica como forma de conhecimento. $O$ autor ressaltou, porém, que essa não é uma questão de métodos e procedimentos. "Mas não são essas coisas, as técnicas e os processos determinados, que definem 0 empreendimento. O que define é o tipo de esforço intelectual que ele representa: um risco elaborado para uma "descrição densa, tomando emprestada uma noção de Gilbert Ryle" (GEERTZ, 1989, p.15).

A prática etnográfica incluí em seus instrumentos "a observação direta de comportamentos, a observação participante (quando há um maior envolvimento no cotidiano do grupo pesquisado), coleta de depoimentos, história de vida, narrativas orais..." (MAGNANI 1993, p.7) Esta prática proposta por Malinowski introduz o pesquisador no mundo "nativo".

O autor também destacou que o pesquisador deve ter claro que "seja qual for seu recorte metodológico, um determinado bairro, instituição ou seita religiosa, ou ainda outro objeto de pesquisa, recomenda o reconhecimento 
de que este objeto faz parte de uma rede mais complexa" (MAGNANI 1993, p.5).

O exercício de tornar o estranho familiar e o familiar estranho constitui movimento fundamental para apreensão da realidade por parte da prática antropológica. Tornando possível, desta forma, uma visão menos contaminada pela naturalização dos fatos cotidianos, possibilitando perceber os vários sentidos e significados presentes nas práticas dos diversos atores sociais.

Assim sendo, a escolha da antropologia justifica-se pelo próprio objetivo da pesquisa que envolve a prostituição e o consumo de substâncias psicoativas, conhecidas genericamente como "drogas", neste caso o crack, como comenta Velho (1994) "(....) A contribuição da antropologia para a compreensão desta problemática consiste em mostrar como existem $n$ maneiras de utilizar as substâncias, em função de variáveis culturais e sociológicas. Estas não só se somam, como complexificam as distinções que possam ser registradas ao nível da análise bioquímica" (VELHO 1994, p.24).

Uma outra questão refere-se à neutralidade. Segundo Silva (1993), esta questão torna-se mais presente ao tratar de temas ligados a "identidade, gênero, promiscuidade sexual, inversão, marginalidade..." Em seu trabalho, procurou não ter uma "preocupação particular com a neutralidade. Contudo há uma outra preocupação: a que, desistindo da isenção, mergulhemos irresponsavelmente no lamaçal da subjetividade". (p.147)

Sobre essa questão VELHO (1985), comentou:

Esse contato pessoal, direto, faz com que os padrões de objetividade científica tradicionais tenham de ser encarados com certa reserva. Por isso mesmo, o trabalho do antropólogo tende a assumir cada vez mais a dimensão da 
intersubjetividade. Não se trataria, então, de procurar abstrair os aspectos individuais, idiossincrasias pessoais etc., mas sim procurar encará-los como parte da situação da pesquisa (VELHO 1985, p.26).

MINAYO (1994) também tratou deste tema, porém para a autora, devido a especificidade das ciências sociais, a neutralidade e objetividade não se tornam realizáveis, mas apontou para a possibilidade da:

objetivação que inclui o rigor no uso de instrumental teórico adequado, num processo interminável e necessário de atingir a realidade. $\mathrm{O}$ que se pode ter dos fenômenos sociais é menos um retrato e mais uma pintura conforme imagem usada por Demp. Isto é, seria impossível se descrever com tal fidedignidade a realidade que ela se tornasse transparente. A objetividade, isto é, o processo de construção que reconhece a complexidade do objeto das ciências sociais, seus parâmetros e sua especificidade é o critério interno mais importante de cientificidade. A objetivação nos leva a repudiar o discurso ingênuo ou malicioso da neutralidade, mas nos diz que é necessário buscar formas de reduzir a incursão excessiva dos juízos de valor na pesquisa (MINAYO 1994, p.36).

Como, neste estudo, está se tratando de comportamentos estigmatizantes - prostituição e consumo de drogas - julgou-se necessária a contribuição dos interacionistas simbólicos para analisar tais práticas.

Com o início da antropologia urbana, a pesquisa etnográfica deixou de olhar para o outro estranho e distante e passou a olhar para o familiar e próximo; neste contexto, a Escola de Chicago torna-se um dos expoentes da Antropologia Urbana e vem dela a teoria do desvio. Na teoria do desvio, o desviante é entendido como $o$ indivíduo que transgride as normas 
socialmente estabelecidas, intencionalmente ou não, devido a algum defeito caracterológico ou de falha de socialização, sendo marginalizado por isso.

Nessa concepção, o desvio é entendido como algo que o indivíduo traz em si e que o afasta do desenvolvimento ideal. Os interacionistas simbólicos, por sua vez, irão entender o desvio como conseqüência da aplicação, pelos outros, de sanções dirigidas ao indivíduo que apresenta comportamento diferente dos socialmente estabelecidos passando, dessa forma, a ser rotulado por tal comportamento. Desse modo, não entendem o desvio como algo inerente ao indivíduo, mas como socialmente produzido. Esta produção se faz com o intuito de manter a ordem social

\begin{abstract}
Quero dizer que os grupos sociais criam o desvio ao estabelecer as regras cuja infração constitui desvio e ao aplicá-las a pessoas particulares, marcando-as como outsiders. Sob tal ponto de vista, o desvio não é uma qualidade do ato que a pessoa faz, mas sim a conseqüência da aplicação por outrem de regras e sanções ao "transgressor". O desviante é aquele a quem tal marca foi aplicada com sucesso, o comportamento desviante é o comportamento assim definido por pessoas concretas (Becker 1966 citado por VELHO 1985, p.23,24).
\end{abstract}

VELHO (1985) propôs uma relativização do conceito de desvio. Em seu livro "Desvio e divergência" discutiu a necessidade de se trabalhar com o conceito do desvio de uma maneira mais relativizada, superando a camisa de força de preconceitos e intolerâncias, deixando de ser visto como patologia com visões que variam de um psicologismo a um sociologismo de produção individual e fragmentada, desvinculada da sociedade e cultura, e sim como uma interação indivíduo sociedade e/ou cultura: "Não se trata de negar a especificidade de fenômeno psicológicos, sociais, biológicos ou culturais, mas sim reafirmar a importância de não perder de vista o seu caráter de inter-relacionamento complexo e permanente"(VELHO 1985, p.19). 
O autor discutiu, ainda, que o "desviante" não está fora de sua cultura, na verdade faz uma leitura divergente das regras sócioculturais estabelecidas, e chamou a atenção para o caráter político que existe entre o conflito rotulador/rotulado, pois de acordo com a força que um grupo assume na sociedade, fará com que defina, o que e quem serão considerados desviantes.

\subsection{Descrição da região}

A região aqui denominada de "região da Luz", corresponde aos bairros da Luz, Bom Retiro e Santa Ifigênia. Apesar de administrativamente serem bairros distintos, as ruas que formam o circuito da prostituição, tráfico e uso de crack, roubos e moradia são ruas limítrofes desses três bairros (Anexo 1).

O bairro da Luz é cortado pela Av. Tiradentes que o divide em duas partes. De um lado, fica a rua São Caetano famosa pelo comércio de vestidos de noivas e também as ruas onde se faz o comércio de ferramentas e ferragens, como a rua Florêncio de Abreu, do outro lado fica a região em que se fez o estudo que é composta pelos bairros da Luz, do Bom Retiro e Santa Ifigênia.

O Bom Retiro é um bairro que, a partir de 1940 com a chegada dos imigrantes de origem judaica, passou a comercializar confecções. Atualmente, vem sofrendo algumas alterações na configuração de sua população desde a chegada de imigrantes coreanos nesse comércio. No bairro de Santa Ifigênia, o que predomina é o comércio de equipamentos eletro-eletrônicos, principalmente na rua Santa Ifigênia.

\section{Descrição do Campo}

Descendo do metrô na estação Luz segue-se pela saída em que se tem acesso às ruas Brigadeiro Tobias, onde se situa o prédio do Departamento Estadual Investigações sobre Narcóticos da Polícia Civil DENARC, e a Rua Mauá onde, de um lado, ocupando toda a sua extensão 
fica a Estação da Luz (ferrovia Santos - Jundiai), com vários camelôs vendendo desde frutas até equipamentos eletrônicos.

Às portas da estação algumas pessoas vendem passes de trens e ônibus e disputam espaço com as mulheres e meninas que fazem programas sendo que, umas estão arrumadas, outras nem tanto e algumas estão sujas. Do outro lado dessa rua há várias lojas que vendem roupas e sapatos; açougues, bares, lanchonetes, farmácias, hotéis e até um cinema que exibe filmes do chamado "sexo explícito".

Os prédios estão bem deteriorados, principalmente na parte superior onde estão localizados os quartos dos hotéis. Mal se consegue andar por esta calçada ou mesmo estando do outro lado da rua, ver as lojas, devido ao grande número de camelôs que se aglomeram com suas barraquinhas competindo com os mesmos produtos vendidos pelas lojas. Nessa rua não existe a predominância de determinado tipo de comércio, vende-se de tudo.

A lógica deste espaço é a de atender as pessoas que passam a caminho de casa para o trabalho ou do trabalho para casa, ou que buscam a região central de São Paulo ou o acesso ao metrô, e moram nas cidades periféricas que compõem uma parte da grande São Paulo, atendida pelos trens suburbanos que passam por essa região. A população que circula por este espaço é de baixo poder aquisitivo.

Seguindo por esta rua em direção a Estação Júlio Prestes, passa-se pela rua Cásper Libero de descrição similar. Adiante chega-se às ruas Couto de Magalhães, Dos Protestantes, Do Triunfo, Dos Gusmões, Largo e rua General Osório, sendo que do outro lado ficam o antigo Prédio do Departamento de Ordem Política e Social - DEOPS - e a Estação Júlio Prestes que liga o município de São Paulo com a Região Noroeste do Estado (ferrovia Sorocabana). Voltando, passa-se pelo viaduto Couto de Magalhães e chega-se à Praça da Luz onde há outra entrada para a Estação da Luz com várias mulheres, meninas e alguns homens parados, além dos pontos de lotação. 
A Praça circunda todo o Parque da Luz. Fazendo a volta pelo Parque da Luz e deixando a Avenida Tiradentes atrás e seguindo em direção à rua José Paulino, chega-se a porta de entrada da região das confecções, cruzase a rua Prates onde há uma Unidade Básica de Saúde e alcançando a rua Ribeiro de Lima com vários bares e restaurantes que as mulheres freqüentam em busca de clientes. Indo para o lado esquerdo chega-se à rua Samuel Brener em que se situa a Casa de Convivência Luz, local que muitas das mulheres que circulam na região freqüentam para tomar banho, lavar roupa, buscar preservativos, pedidos de segunda via de documentos, encaminhamentos médicos, conversar, descansar ou participar das demais atividades que a casa oferece.

Seguindo por esta rua chega-se à rua Afonso Pena onde alguns restaurantes são também "ponto" de encontros; uma garagem do quartel da Polícia Militar situada na rua Ribeiro de Lima, e vê-se novamente uma das entradas do Parque da Luz, sendo que a principal fica na Av. Tiradentes, ao lado da Pinacoteca do Estado. Na praça, circundando todo o parque ficam camelôs e vários moradores de rua, muitos deles usuários de crack. Dentro do parque ficam muitas mulheres de todas as idades arrumadas discretamente, que utilizam o local para buscar clientes. Circulam ali homens que buscam essas mulheres, homens que fazem programas com homens e cafetões.

\section{Região da crackolândia (antiga "boca do lixo")}

As ruas que compõem a crackolândia são: Rua Dos Gusmões, Protestantes, Triunfo, Couto de Magalhães e Largo Gal. Osório (anexo 2). Cheias de hotéis decadentes, prédios abandonados e deteriorados, bares e algumas casas de comércio duvidoso, porque, na verdade não existem placas que as identifiquem, são um tanto vazias de mercadorias sejam elas quais forem. Existem sempre homens em suas portas muito mal vestidos e, às vezes, alguns caminhões parados. 
Nas calçadas dessas ruas o lixo se amontoa e é de toda espécie: restos de comida, caixas, papéis higiênicos usados, restos de móveis, tudo vindo, provavelmente, dos hotéis da região. Esses hotéis têm várias funções como de moradia, local para "fazer programas", tráfico de drogas principalmente o crack - e também local para fumar as pedras de crack. Há cerca de três anos essas ruas tinham uma movimentação intensa dos "pedreiros" que é a designação que se da aos usuários de crack chegando a quase 100 pessoas por dia andando, jogadas pelo chão junto ao lixo, agachadas, todas fumando ou buscando o crack. Pela manhã o local apresentava uma circulação de menor movimento ao contrario da tarde, pois este seria o horário em que chegavam as pedras na "bocada", segundo relatos de meninos que viviam pelo local.

Atualmente, depois de uma operação policial que começou no final de 1997, entre outras que se seguiram, a região mostra uma presença menor dessa população. Existe alguma circulação, mas é muito pequena em comparação com a que ocorria anteriormente. Hoje a busca e o uso das pedras acontece dentro dos hotéis ou espalhados pelas ruas próximas, desde as imediações da estação Júlio Prestes passando pela crackolândia e estação da Luz e beirando todo o parque da Luz, e também por outros pontos da região central da cidade como o Anhangabaú, República, Praça da Sé e Parque D. Pedro.

\subsection{A Pesquisa}

No trabalho de campo procedeu-se da seguinte forma: observações em que deixava que os fatos e relatos do cotidiano surgissem espontaneamente.

Alguns dados dos usos do crack e histórias de vida foram obtidas de forma mais dirigidas, outros em conversas informais forma que, aliás, se mostrou muito mais proveitosa. Registrou-se em diário de campo. 
Convém recordar, a propósito, o modo de operação das pesquisas etnográficas que em busca dos padrões culturais mais abrangentes que dão sentido a ritos, costumes, mitos, etc., trabalham tanto com a observação direta destes fatos como também com as explicações dos membros da comunidade sobre a sua prática. Eunice Durham (1980b) assinala que a utilização simultânea de ações e discursos como evidência igualmente válidas para a construção de sistemas que permitam apreender o significado, implica conceber a relação entre regra explícita e conduta, ou entre discurso e ação de um modo particular (MAGNANI 1998, p.58).

Quanto à veracidade dos fatos relatados pensava-se que, muitas vezes, algum relato poderia não ser real, mas ainda assim, deveria ser levado em conta como uma produção de um determinado espaço em que, de alguma forma, as relações que se estabelecem, o reforçam e/ou legitimam como espaço de violência, de exclusão; de medo ou piedade. Porém, poucas vezes essa produção (como produção ficcional) foi notada. Muitas conversas e relatos eram referenciados por outros atores e em momentos e espaços diferentes no circuito de circulação escolhido para a pesquisa. Esses espaços foram percorridos durante a tarde e à noite. 


\section{Caracterização da região da pesquisa}

\subsection{A entrada no campo}

No final de 1996 buscou-se contato com pessoas que desenvolviam algum trabalho com mulheres que faziam programa na região da Luz. O que resultou no encontro com um grupo da Pastoral da Mulher Marginalizada da Arquidiocese de São Paulo que, juntamente com o Serviço a Mulher Marginalizada (uma ONG também ligada à Pastoral da Mulher), mantinham duas casas de apoio para essas mulheres na região central, chamadas de "Casas de Convivência" as quais iniciaram suas atividades em 1992; uma delas, no bairro da Liberdade e a outra, no bairro do Bom Retiro, bem próximo à Estação da Luz.

Essas casas faziam parte de um trabalho que havia começado em 1988, com religiosos, seminaristas e leigos que trabalhavam voluntariamente nas ruas da baixa prostituição agregando-se posteriormente membros da Igreja Metodista. Os objetivos da Pastoral são descritos a seguir:

Nosso objetivo primordial é o resgate da dignidade da mulher e da adolescente prostituta. Compreendemos por esse resgate, a capacidade de exercer sua cidadania, sendo sujeito de direitos e de deveres, responsável por seus filhos e a capacidade de amar a si mesma, exercer os devidos cuidados sobre sua própria pessoa: cuidados com a sua saúde física e mental, auto-proteção e segurança. Isso tudo envolve ações diretas de orientação e educação para a preservação da vida, vivências positivas grupais e vivência do amor a partir de todas essas experiências, na Casa de Convivência da Mulher.9

\footnotetext{
${ }^{9}$ Trecho retirado de projeto da Pastoral da Mulher Marginalizada para captação de recursos, de autoria da equipe de agentes, sem data.
} 
Após alguns contatos, visitou-se a casa do Bom Retiro onde as mulheres podiam tomar banho, lavar roupas, cuidar dos cabelos e se alimentar, além de fazer cursos de alfabetização e trabalhos manuais. Posteriormente a Pastoral fez parceria com a Secretaria da Criança, Família e Bem Estar Social do Estado de São Paulo, conseguindo subsidiar cursos profissionalizantes de cabeleireira e manicure, e também pagar salários para manter o funcionamento diário da Casa, visto que com o trabalho voluntário esta só funcionava três dias por semana e apenas no período da tarde. Também fazia parte dos serviços oferecidos pela Casa a busca por segunda via de documentos e encaminhamentos médicos.

Após estabelecer o contato com a Casa, descobriu-se que existia outro grupo da Pastoral que percorria as ruas em algumas tardes da semana. Marcou-se encontro na Estação da Luz com a religiosa que coordenava o trabalho de rua. Essa foi a primeira dificuldade de inserção no campo.

O trabalho de campo sempre coloca questões, ou melhor, dificuldades a serem encaradas com sensibilidade. A dificuldade de inserção no campo é tema recorrente, em vários trabalhos antropológicos, entre os quais destacase o trabalho etnográfico realizado por SILVA (1993) sobre os travestis do bairro da Lapa no Rio de Janeiro.

Segundo o referido autor, fica difícil definir bem qual é o começo, porém cabe, nestas circunstâncias, ter clareza de que existem inúmeras possibilidades para o seu início; talvez o começo mais adequado seja aquele que possibilite algum tipo de inserção no campo.

SILVA (1993), em princípio, tentou uma abordagem apresentando-se como pesquisador; porém essa maneira não lhe facilitou, em nada, o acesso ao universo a ser estudado. Nas tentativas seguintes foi confundido com "policial" ou "careta", por fim, após um período de ausência no campo, retornou como um simples "bebedor de cerveja"...Foi apenas neste momento 
que o "universo então se abriu com todo o seu potencial" (SILVA 1993, p.150).

A dificuldade vivenciada no inicio causou espanto, porque não partiu dos atores sociais, objeto do estudo, e sim de algumas das pessoas que desenvolviam o trabalho de apoio social junto às mulheres. Existia um grupo que atuava nas ruas da região da Luz e que inicialmente mais interessou, tal grupo, apesar de pertencer a mesma Pastoral não trabalhava em parceria com a Casa, por algumas divergências políticas e por acreditar que o trabalho na rua ${ }^{10}$ não poderia ser deixado em função do trabalho na Casa.

A religiosa que coordenava a atuação na rua mostrou-se totalmente avessa a qualquer tipo de pesquisa com as mulheres. Perguntava o que se daria, em troca, a elas, que já eram tão exploradas. E dizia que não acompanhava e procurava não incentivar inclusive a padres que já haviam tentado fazer o mesmo. Ainda dizia que depois de fazer a pesquisa as pessoas desapareciam não contribuindo em nada para a melhoria da qualidade de vida das mulheres.

Como este encontro se deu na rua, na Estação da Luz, algumas vezes a conversa foi interrompida para falar com algumas mulheres que também freqüentavam a Casa de Convivência. A religiosa informou que uma das mulheres era traficante de crack em seguida a chamou e perguntou se ela estava com "pedras" na revista da Avon que carregava, a mulher negou, então a religiosa disse a ela que a pesquisadora era da polícia, fato que foi negado, mas a mulher não esboçou nenhuma reação e se afastou.

Na Casa de convivência, ao contrário, a idéia da pesquisa foi bem recebida pela coordenadora. Entretanto, descobriu-se que atrás da boa vontade existia o interesse de envolvimento no trabalho voluntário, o que ocorreu de fato, deixando pouco espaço para a conversa com as mulheres de uma forma mais solta.

\footnotetext{
${ }^{10}$ Atualmente esse grupo não desenvolve mais essa atividade.
} 
Depois de um período de ausência voltei a freqüentar a casa e informei à coordenadora que passaria a circular pelas ruas, alguns agentes pastorais acharam que seria interessante fazerem o mesmo. A partir de então em algumas ocasiões passei a ter companhia em meus percursos ${ }^{11}$, em que se distribuíam preservativos. O preservativo se mostrou um facilitador para contatos na rua, não só para o desenvolvimento da pesquisa, como para os trabalhos de outros grupos religiosos e de saúde.

Durante o campo foram promovidas discussões sobre DSTs/AIDS e muitas vezes, eram esclarecidas dúvidas sobre o tratamento da sífilis em conversas com as mulheres. Já no final do campo ocorreram algumas prisões arbitrárias de mulheres, sob o pretexto de estarem incomodando os lojistas, apesar dessas prisões ocorrerem após o fechamento das lojas.

Nessas ocasiões procurou-se os policiais e promoveu-se encontro entre alguns membros da Pastoral, com o apoio de um deputado e um policial de alto escalão da Policia Civil que lutam pela defesa dos Direitos Humanos. Também houve participação, em algumas reuniões, de profissionais da área da saúde, algumas pessoas ligadas a ONGs que desenvolvem trabalhos na região e algumas mulheres e travestis que fazem programa. O objetivo era o de propor e apoiar uma organização dos "profissionais do sexo", incluindo formação desta noção e a defesa de seus direitos. Essa questão será discutida mais adiante.

Esse envolvimento com todas as questões e discursos que estão presentes nesse circuito facilitou uma melhor compreensão e inserção no meio. A preocupação inicial que por ser identificada com algum grupo que desenvolve atividades na região - e são muitos - pudesse padronizar os relatos produzindo um discurso que julgavam esperado, mostrou-se inconsistente.

\footnotetext{
${ }^{11}$ O que justifica que apareça no diário de campo falas na primeira pessoa do singular e na primeira do plural.
} 
Primeiro, porque os habitúes sabem quem são os atores que circulam pela região e os identificam de acordo com o manejo dos códigos de conduta do local, portanto não seria identificada com um deles.

Segundo, porque de acordo como se estabelece o contato se determina o tipo de discurso produzido, não importando muito em que categoria te enquadrem, como irmã (da igreja católica), tia, profissional da saúde, ou outro grupo religioso.

$\mathrm{Na}$ verdade o vínculo, a confiança e a não reprovação do estilo de vida que levam foram fatores fundamentais para a inserção no meio. $O$ fato de circular pelos mesmos lugares, entrar nos mesmos bares e não temer ser confundida com uma mulher que "faz programas", estabeleceu vínculos de confiança e respeito gerou situações interessantes e, muitas vezes, divertidas.

Quando estamos indo embora encontramos Amalha ${ }^{12}$ na Estação do metrô Luz, que brinca conosco como se estivesse brigando, logo passa uma mulher e esbarra em Amalha com cara de poucos amigos e para um pouco mais distante, depois diz: "pensei que fosse briga. Já estava me preparando para ajudar a bater nelas".

As observações e conversas foram realizadas na rua, e dentro do circuito escolhido para a pesquisa que incluía a Casa.

\subsection{As mulheres da Luz}

As mulheres que fazem programas nessa região são procedentes das mais variadas regiões do país. São de todas as idades, não existindo - à primeira vista - predominância de cor. Possuem escolaridade muito baixa. Algumas moram em hotéis e pensões da região, (quando conseguem dinheiro) procuram albergues públicos e, muitas vezes, dormem na rua,

\footnotetext{
${ }^{12}$ Todos os nomes são fictícios, mas conservam familiaridade com o léxico dos nomes utilizados pelas mulheres.
} 
outras, em cidades e bairros periféricos ao longo da ferrovia e, segundo elas, mantém a família com o dinheiro dos programas.

Em alguns casos, a família desconhece a atividade que desenvolvem; em outros, estão na segunda geração deste trabalho, com mãe e filha fazendo "ponto" lado a lado. Muitas delas têm "cafetões", um assunto não comentado abertamente, muitas vezes porque não os consideram assim, visto que possuem uma relação marital com esses homens. O preço dos programas é de $R \$ 30,00$ incluído os $R \$ 5,00$ do hotel, podendo chegar até $R \$ 20,00$ sem o pagamento deste. Dependendo da necessidade, este preço pode baixar. Em um bom dia de trabalho, que são os dias em que os homens que as procuram recebem pagamento, pode-se fazer 5 programas. Mas, todas reclamam muito do movimento atual, dizendo estar "muito fracassado". A duração do programa é de 30 minutos, mas geralmente não chega a ser consumido todo este tempo.

\section{O Programa}

O termo programa, no contexto estudado refere-se a encontros entre parceiros para troca de práticas sexuais por dinheiro. Os tipos de programas oferecidos são: vaginal, oral e anal, podendo serem feitas todas as práticas em um único programa sendo chamado de "programa completo", e que em geral custaria mais caro. Também mencionam outros tipos de programas propostos por alguns clientes que as procuram apenas para assistir a relação sexual com outro homem, ou para acompanhá-los aos hotéis para que usem o crack.

Os programas são negociados nos pontos em que as mulheres ficam, e realizados, na sua maioria, nos hotéis. Estes por sua vez não têm muitas preocupações com a higiene dos quartos e mesmo com a roupa de cama. Em vários hotéis simplesmente esticam os lençóis no intervalo de cada programa e, muitas vezes, nem isso ocorre. 
Segundo relato das mulheres os clientes são homens separados ou sozinhos, na maioria, e também casados. Com idade superior a 28 anos. Dizem que os mais novos geralmente aparecem porque tem medo de usar 0 crack sozinho e então chamam as meninas para usar junto e dão algumas pedras para que elas fiquem com eles no hotel "Às vezes até transam. Já estão lá mesmo".

A maioria das mulheres que fazem "ponto" próximo das estações de trens e metrô tem como clientes operários da construção civil, da indústria e aposentados, das mulheres que ficam nas imediações da rua Santa Ifigênia tem como clientes (na maioria), donos das lojas de eletro-eletrônicos, os clientes dessas lojas e policiais.

De maneira geral, atribuem também à crise econômica o fraco movimento que enfrentam. Porque, segundo elas, os homens pagavam 0 programa com o dinheiro das horas extras e não mexiam no dinheiro que levariam para a família e/ou despesas.

São considerados clientes os que mantém uma certa assiduidade com determinada mulher, quando são eventuais dizem apenas: "fiz um programa". Também chamam pejorativamente alguns homens de "prego", que são homens que pagam para "dar uma e querem dar duas, três", ou então quando têm dificuldade de "gozar" e demoram na tentativa.

\section{Relações de amizade com clientes}

Saímos do Parque. Comento com ela sobre o grande número de homens que ficam por ali. Ela disse que são clientes, mas que nem sempre fazem programas, vêm ali para conversar porque acabam se tornando amigos. Me aponta um senhor de uns 60 anos aproximadamente e disse: "Esse aí era bem de vida. Perdeu tudo no jogo. Agora mora num quartinho na casa de uma irmã, mas ele ultimamente anda meio sujo, deve ter acontecido alguma coisa com ele". 
Com alguns clientes estabelecem relações de amizade em que ambos conversam sobre problemas da vida particular ou da atividade que exercem e em alguns casos as mulheres chegam a ser ajudadas em dificuldades financeiras, mas em geral essa ajuda nunca é de grande valor monetário. Em alguns casos trocam remédios e até "simpatias" para curar alguma doença.

\section{As mulheres que usam crack}

No primeiro contato com o campo, imaginava-se que todas as mulheres que usavam "crack" eram mulheres que faziam programas, mas na verdade existem outras formas de atuação neste espaço. Existem as que são moradoras de rua e as que traficam e/ou roubam. Algumas delas que não fazem programas e circulam nesse espaço se auto-denominam de "sapatões"; estas traficam e roubam. As usuárias de crack têm até 40 anos, baixa escolaridade e a raça predominante é a negra e os afro-descendentes. Algumas já cumpriram penas judiciais por tráfico ou envolvimento com drogas. Referem-se aos motivos das prisões pelos números do código penal, "peguei um 12", "peguei um 16". Tiveram a primeira gravidez entre 13 e 15 anos e têm mais de 2 filhos. Casaram-se muito novas e já tiveram, no mínimo, 3 companheiros. Os filhos moram com familiares, geralmente com mães ou irmãs ou foram dados para adoção e, em alguns casos, tomados pela justiça. Estão nas ruas em média há mais de 5 anos, e o primeiro contato com drogas foi com maconha e/ou cocaína. Todas usam o crack há mais de 2 anos, no mínimo. Algumas relataram já ter parado de usá-lo por um período de aproximadamente um mês.

Basicamente não existe diferença entre as mulheres que consomem crack e as mulheres que fazem programas, elas vêm do mesmo extrato socioeconômico e têm histórias de vida semelhante.

Estas mulheres não são organizadas e não se constituem em um grupo único, existindo entre elas muita rivalidade. Formam grupos de amigas, andam juntas e só tentam alguma forma de conduta mais coletiva 
quando projetos de reurbanização do bairro ou a ação da polícia passa a agredi-las, expulsando-as dos locais em que fazem "ponto". Elas não se referem como "trabalhadoras do sexo", talvez por não terem o discurso das mulheres organizadas; preferem antes se referir a atividade que exercem dizendo: "faço programas". Só dizem que são prostitutas quando referem-se pejorativamente, dizendo "sou prostituta mesmo".

Um dos problemas "visíveis" da entrada do crack nesse meio é o ingresso na prostituição de meninas, cada vez mais jovens, muitas delas são meninas que na sua maioria estão em "trânsito para a rua" (ADORNO 1996).

A prostituição aqui designada de prostituição infantil, não está confinada a um tipo de serviço organizado oferecido como uma especialidade para uma demanda cativa como parece ocorrer em algumas regiões do norte e nordeste do país e sim como um dado cronologicamente observado. $O$ ingresso das mulheres mais velhas na prostituição geralmente se deu na adolescência relatam idades entre 15 e 16 anos, porém precedido de certo aprendizado. Contudo, o que se observa no universo estudado é que com o uso do crack essa faixa etária diminui caindo para 10 e 11 anos e mesmo para as adolescentes entre 15 e16 anos a iniciação na atividade, muitas vezes, não é precedida de nenhum aprendizado formal com mulheres mais experientes, a não ser quando são cafetinadas por uma delas. Em geral aprendem algumas formas de conduta pela observação e por ouvir a conversa das mulheres com quem se relacionam. Algumas mulheres dizem que tentam dar conselhos, mas estas não as escutam. Conhecem o crack e vislumbram na prostituição a possibilidade de obter ganhos para conseguir comprar a "pedra" ou pela própria "pedra", começam oferecendo como prática sexual a "chupetinha".

Abaixo trecho do diário de campo com a história de vida de uma menina.

Chegamos à porta da Estação da Luz do lado do Parque nesse horário (21:00hs) geralmente ficam mulheres que usam crack que em sua 
grande maioria é de adolescentes e crianças. Enquanto caminhávamos uma adolescente pediu: "Tia, dá um cigarro?" Dizemos que só temos camisinha, ela deu um sorriso e aceitou a camisinha. Disse: "É bom, eu faço programa". Começou a conversar. Se chama Cíntia, disse: "Eu tenho 15 anos, tia, eu tô fazendo programa há pouco tempo, eu nem sei porque entrei nessa vida, eu ficava pela rua usando droga, aí as meninas falavam pra mim "fazer programa" e aí eu comecei." Perguntei de onde ela era. Disse que era de Arthur Alvim. Perguntei se tinha família lá. Ela disse que sim, mas, que há muito tempo ficava pela rua usando droga. Outra adolescente passou e ofereci "camisinha", ela disse: "Eu não faço programa." Então perguntei: "Mas você não transa?" Ela respondeu: "Não". Deu um sorriso e continuou andando. Perguntei a Cíntia se alguém Ihe deu alguma dica de como se defender nos "programas" para não sofrer violência e para receber 0 pagamento. Ela disse: "Não, mas eu só transo com o dinheiro na mão, e assim que o cara acaba eu já vou saindo, senão eles querem dar duas, três e só pagar uma. Se o cara fica insistindo eu falo que tenho que sair que tem um traficante me esperando e que ele fica armado, e vou embora. Às vezes antes do cara acabar eu vou embora e deixo o cara na mão. Uma vez eu saí com um cara e o pau dele era enorme e grosso, eu falei que não transava, fui embora. Você acha?! Aquilo grosso e grande daquele jeito ia me machucar, quando a gente transa com um cara desse dói aqui ó (mostra a altura do útero)." Perguntei a ela se os homens estavam usando camisinha, ou estavam propondo pagar mais para não usar. Disse: "É, eles falam que com camisinha perdem o tesão." Perguntei quanto ela estava cobrando o "programa", ela respondeu que era $R \$ 15,00$, perguntei quanto ofereciam para "transar" sem "camisinha". Ela disse que eles ofereciam $R \$ 20,00$ pelo "programa". Comentei que uma vida valeria muito mais que isso. Ela disse: "Nunca transo sem camisinha, porque não quero pegar AIDS (sic), mas tem menina que usa crack que transa sem. Eu uso crack, mas não transo sem camisinha"(sic). Perguntamos se ela conhecia a menina que havia sido estuprada, ela ficou assustada : "O que, tia?". Contamos a história que nos relataram. Dizemos que não estamos querendo assustá-la, mas alertando 
para que tome cuidado, pois o homem iria ser solto. Ela comentou: "Tem cara que chama pra transar na linha do trem, na casa dele. Eu nunca vou eu só transo no hotel, porque no hotel tem portão, e se o cara fizer alguma coisa ou não querer pagar e sair correndo, o cara do hotel segura. Uma vez um cara me chamou pra transar dentro do Parque e eu fui. Quando chegou lá ele queria transar por trás, e por traz eu não transo, ele ficou insistindo, eu comecei a bater nele, dá pernada, gritar aí ele me soltou e eu vim embora, daí ele me chamou pra transar na casa dele e eu não fui." Ela perguntou se éramos do posto, dissemos que não, que fazíamos parte da Casa de Convivência, mas ela não conhecia. Voltamos a falar de "camisinha" que deve-se usar a camisinha, inclusive no sexo oral, então ela disse: "Eu não faço sexo oral, uma vez eu fui fazer com um cara, mas é ruim fica dando ânsia, porque eles querem enfiar tudo, ainda seguram sua cabeça com força empurrando assim (força a minha cabeça, para mostrar) dá um medo que vai te machucar". Comentei que se ela fosse fazer algum dia, tinha que colocar camisinha antes de começar, porque na "agüinha" que saía, se a pessoa tivesse o vírus já contaminaria, não só com AIDS, mas também com outras doenças. Ela disse: "Ah, eu sei não o gozo, né? Aquela água branquinha. Só aquela agüinha..." Confirmei e falei que inclusive, poderia acontecer de se ficar grávida só com aquela "agüinha". Ela perguntou: "A tia é casada, né? E sorri. Falei que era, mas que sabíamos dessas coisas porque trabalhávamos com prevenção a AIDS. Ela nos disse que nunca menstruou. A agente pastoral disse que mesmo assim, ela poderia engravidar, e que poderia ser que ela não menstruasse por não se alimentar corretamente. Dizemos a ela para procurar o posto e ver o que seria. Ela disse que já havia feito o teste da AIDS e que não tinha. Dizemos que ela que deveria ir para saber da menstruação. Perguntei a ela como foi a primeira vez que "fez programa" o que sentiu, ela contou: "A primeira vez eu não tinha nem corpo ainda. Eu ficava pela rua, e tinha um taxista que vivia querendo transar comigo, as meninas viviam dizendo pra eu transar com ele aí um dia eu fui, quando ele começou a enfiar eu comecei a chorar, não queria mais, mas depois parou de doer". Eu perguntei, mas foi a primeira vez 
que você transou? E ela confirmou: "É tia, eu não tinha nem corpo. Esses caras você pensa que eles querem mulher velha, eles querem menina novinha". Perguntei se foi de graça. Ela disse: "Eu era boba cobrei 10 reais". Pensei que não havia grande diferença do preço que cobrava agora. Ela estava agitada, mas era muito amistosa, notei que em alguns momentos ela se desconcentrava da conversa, mesmo gostando de estar conversando, disse que estava querendo arranjar mais 4 reais para poder comprar uma pedra de 5 reais. Disse que estava com pneumonia por fumar crack demais, tomar chuva e muito sorvete. Perguntei se ela ficava na crackolândia e ela disse que só ía lá para buscar a pedra, mas que fumava ali na porta da estação e fez questão de nos mostrar onde era. Perguntei se ela dormia no hotel e ela disse que, às vezes, no hotel e, em outras na rua. Nos despedimos e vamos em direção ao metrô.

Esse relato descreve bem as situações de violência a que estão sujeitas e como ingressam na atividade descobrindo nas próprias situações como lidar com elas. Em alguns momentos percebe-se a inexperiência, principalmente no que se refere ao preço. No primeiro programa acha que foi "boba" por cobrar $R \$ 10,00$, mas atualmente cobra apenas $R \$ 5,00$ a mais. E apesar de não oferecerem algumas práticas sexuais, por julgarem desagradáveis e/ou repugnantes e, talvez, por inexperiência, o fato de serem jovens e cobrarem menos compensa as poucas opções das práticas oferecidas.

Analisando os dados obtidos durante as observações no campo, temse a impressão de que para as mulheres da região da Luz existe a mesma identidade geral ou, como se sabem reconhecidas, que é a de prostituta perpassada pelas representações sociais desta atividade. Elas também fazem parte dessa produção social, inclusive reinventando e/ou reforçando essas representações, confirmando as histórias esperadas pelos seus ouvintes sobre a sua trajetória para a "vida fácil". Vemos nesse comportamento, como descreve GASPAR (1985), uma forma de manipulação da identidade estigmatizada visando, dessa forma, explicar a 
própria conduta de uma maneira em que não sejam inteiramente responsáveis por se prostituírem (ou não tendo sua identidade totalmente tomada por essa prática) sendo vítimas de uma situação em que, como mulheres frágeis, não tiveram outra opção. Sobre o conceito de manipulação nos fala VELHO, et. al. (1978):

"Não é necessário ter consciência e percepção do sistema enquanto totalidade (problemática) para influênciá-lo através de ações e interpretações em que os símbolos são manipulados e transformados diante de circunstâncias e situações novas." (VELHO e VIVEIROS 1978)

No seio dessa identidade geral atribuída, existem as representações que as mulheres fazem de si mesmas, portanto, não dá para falar em uma identidade única, pois que, nessa atividade ("fazer programas") existe uma divisão entre alto e baixo meretrício e em cada um destes, existe subdivisões. As mulheres do alto meretrício - que também têm suas subdivisões em garotas de boites, de casas de massagens e scort-girls estabelecem diferenças estigmatizantes com relação às da baixa prostituição e estas, por sua vez, adotam o mesmo comportamento com relação às subdivisões existentes em seu meio. As mulheres que fazem programas no baixo meretrício, ou mais precisamente da "boca do lixo" de São Paulo, localizada nas proximidades da Estação da Luz, estabelecem algumas distinções estigmatizantes de acordo com a idade, a aparência física e indumentária, que demonstra um padrão de consumo diferenciado das demais e, por conseguinte, maior sucesso na atividade. Essas distinções também pesam negativamente sobre as mulheres que usam crack e, entre estas, sobre as que "se trocam por pedras". Como cita GASPAR (1985), esta hierarquização estigmatizante que elas mesmas fazem, na verdade, é uma estratégia de se diferenciar e se afastar da identidade poluída - o nome de guerra também entraria nessa categoria tendo algo que se considere abaixo da sua posição nessa hierarquia terminam por valorizar a situação em que se encontram. 
As hierarquias estigmatizantes também se estabelecem de acordo com o espaço ("ponto") onde esperam seus clientes para oferecer o "programa". Assim, as áreas menos nobres da região são a crackolândia e as portas da Estação de trens e metrô da Luz. As mulheres que esperam por seus clientes nestes locais são referidas pelas outras de "as meninas que fazem paredão", pois ficam encostadas nas paredes e, muitas vezes, chamam os homens que passam oferecendo seus préstimos, assim como fazem os camelôs e vendedores de passes que também ficam por ali.

As que fazem "ponto" na rua na região da crackolândia são mais desprestigiadas, muitos homens não se aventuram a passar por lá temendo ser assaltados. As mulheres usuárias muitas vezes fazem programas pelo preço de uma pedra, ou pela própria pedra, sendo desconsideradas e recriminadas (pelas não usuárias); por esse motivo e por depreciarem o preço do programa.

Pra mim mulher que se troca por pedra não vale nada. Eu uso crack dou a bucêta, mas não me troco por pedra.

Estas dizem que as usuárias de crack fazem o "serviço completo" por $\mathrm{R} \$ 5,00$. O "serviço completo" seria sexo oral, vaginal e anal. "Dessa forma elas desvalorizam o corpo e desvalorizam a gente". Ainda comentam que tendo a preferência dos clientes as meninas mais jovens fazem sexo oral também por esse preço aumentando a concorrência. Costumam chamar as usuárias de crack de "nóias ou noinhas", "crackeiras" e "fedidinhas".

A gente "faz programa" por 30 reais; se o cliente acha muito a gente faz por 25 ou até 20 e ele dá os 5 reais do hotel, agora fica fazendo por 5 reais. Eu tinha um cliente que eu cobrava 30 reais, aí um dia ele foi com uma fididinha por 5 por que estava duro e depois veio me contar. Agora eu não saio mais com esse cliente, por que ele transou sem camisinha com ela, perdi um cliente. 
Não estabelecem distinção entre "fazer programa" pelo preço da pedra ou pela pedra, as duas práticas são chamadas de "se trocar por pedras".

$\mathrm{Na}$ verdade, o uso do crack é responsabilizado por fazer sexo sem o uso do preservativo, estabelecendo-se assim um tipo de "hierarquia estigmatizante" em relação ao "outro", talvez uma forma depreciativa ou defensiva que imputa ao outro os comportamentos mais "estigmatizantes". Assim a "droga" acaba por ser responsabilizada pelos atos das próprias usuárias e não usuárias.

As mulheres que usam o crack e não fazem "programas" censuram as mulheres que o fazem. "Acho errado essas mulheres que se vendem, sou mais roubar e vender pedras"

Os espaços mais nobres para a atividade seriam o Parque da Luz e as ruas Santa Ifigênia, rua Aurora e apenas alguns trechos das ruas Gusmões, Triunfo e Andradas, visto que alguns segmentos destas ruas estão inseridos no espaço reconhecido como crackolândia. As que ficam no Parque da Luz apresentam-se com aparência cuidada e possuem bons atributos físicos, são de todas as idades. Ficar no Parque é também uma estratégia de preservação de sua identidade, pois não ficam à vista de todos porque qualquer um pode ficar ali, não sendo necessariamente para fazer "programas", assim, podem se desvencilhar de encontros com pessoas conhecidas que ignoram a atividade de que elas se ocupam. Além do mais, homens conhecidos que as encontrassem no Parque teriam grandes possibilidades de estar à procura de um "programa", o que mudaria a situação em benefício da mulher, pois se este espalhar a notícia de que ela "faz programas", ela pode contar para esposas e familiares dele que este gasta dinheiro com mulheres.

A determinação de quem vai ocupar estes espaços se dá tanto pela existência de uma hierarquia em que as mais novas, com melhores atributos físicos e as mais arrumadas e limpas serão mais prestigiadas, como por 
laços de amizades com mulheres que já ocupavam o "ponto" ou com donos de hotéis e bares que, muitas vezes estão envolvidos com alguma atividade ilícita, e/ou possuem algum respeito dentre os demais.

Portanto, mesmo que a mulher já não seja tão jovem ou não esteja muito arrumada ela poderá fazer "ponto" em alguns desses lugares, com exceção de mulheres que estejam muito "dominadas" pelo crack. Estas circulam pela estação de trens da Luz e terminam se fixando mais na região da crackolândia.

Dentro desse jogo de qualificação/desqualificação, o componente moral também está presente. As mulheres que usam crack e não fazem "programas", julgam condenável essa atividade, e a desqualificam como estratégia de se conseguir dinheiro. Quando se referem a mulheres que usam crack e "fazem programa" para conseguir pedras, esta condenação se acentua.

Disse que é contra a mulher se "vender e principalmente se "vender por pedra". Comentou: "será que não ficam com isso aqui doendo", apontou para a vagina. "Eu acho que na verdade essas mulheres são é viciadas em sexo". Falou: "Ela vai ficar brava comigo". Aponta para Tereza que realmente escutava a conversa de cara fechada. Continuou falando "eu há 2 anos que não sei o que é um homem. $E$ essas mulheres ainda falam que têm marido, se acha são é cafetão. Ficam bebendo no bar e esperando elas trazerem o dinheiro dos programas e se não trazer apanha".

Acho errado se prostituir, não condeno, mas prefiro vender pedras e roubar do que "fazer programa", tem menina menor que faz chupeta por uma pedra, tá vendo essas aí (As duas crianças que estavam dormindo, e eu pensava que eram meninos. Aparentavam ter 10 anos no máximo) fazem "programa" por pedra, teve um negão que veio e "fez programa" com uma menina de menor. Eu falo que se eu vê eu bato nelas. Eu acho errado, menina de menor "fazer programa". Eu tenho 2 filhos eu sei como é que é, eu não quero pros outros o que não quero pra mim." Comentou que há uns 
dias atrás veio uma mulher e lhe propôs para fazer filme pornográfico para ganhar 100 reais e ela recusou, "acho errado sou mais roubar e vender pedras."

Nota-se, nas falas a presença dos valores morais circulantes nas classes populares, que têm na família com sua normatização sexual, no trabalho e nos bons costumes o modelo a ser seguido. Portanto, se elas não estão participando de todos os valores aceitos na sociedade não estão totalmente fora deles. Quando dizem "sou mais roubar e traficar" estão fazendo uma classificação em que não obedecer aos valores do mundo do trabalho tem um peso menor de desqualificação do que se prostituir. Quando, em outra fala, a mulher coloca os seus filhos como parâmetro, faz menção a uma organização em que a relação sexual faz parte do mundo dos adultos e dentro de alguns padrões de afetividade, portanto, ameaça bater nas meninas para que não enveredem por um caminho que não acha correto, pois não deseja para os outros o que não quer para si. Ainda em outra fala, a mulher taxa como "vício" a atividade da prostituição, ou seja, não é necessidade para ganhar dinheiro e sim a vontade de se satisfazer sexualmente o que motivaria as mulheres.

Existem ainda outros recursos de valorização: deter o poder de alguma forma sobre as demais, ser "boa de briga", conseguir intimidar as demais, ser traficante de crack (muito embora esse tráfico em si não traga grandes lucros), "cafetinar" meninas mais novas geralmente dos 11 aos 16 anos (que muitas vezes buscam, na verdade, as pedras de crack).

Essas mulheres constituem um grupo social inteiramente diversificado e multifacetado, de difícil organização em torno de interesses comuns, pois cada uma desenvolve uma rede de interesses e os classifica de acordo com a interação de suas estratégias de preservação de identidade não profissional e da posição que ocupa na rede hierárquica estabelecida de desvalorização/valorização.

\section{Conflito pelo preço do programa e disputa de "ponto"}


Apesar de existir conflito entre as mulheres que só fazem programas, referente ao "ponto", ao cliente e ao preço, este se evidencia, com maior peso no discurso com relação às mulheres usuárias de crack, pois estas mulheres adultas, adolescentes e meninas consumidoras fazem "programas" pelo preço de uma pedra, $R \$ 10,00$ ou fazem o "programa completo" pelo preço de uma prática apenas: $R \$ 25,00$. As meninas de 11 até 15 anos geralmente oferecem sexo oral, por $\mathrm{R} \$ 10,00$ e por serem jovens atraem os "clientes" das mulheres mais velhas.

(....) Aí acaba a pedra elas vão com aquele olho parado atrás de cliente de novo, e fazem serviço completo por 5 reais. Elas não valorizam por que nem sentem nada. Agora a gente vai ficar agüentando dor, homem sujo em cima da gente por 5 reais? (....) Perguntei o que era o serviço completo Marta responde: "dá a buceta, dá o cú, faz chupetinha". As outras riram e falaram: "Isso é jeito de falar? Ela respondeu: "Já falo logo como é mesmo"

Em uma tarde, três mulheres que faziam programas e não eram consumidoras de crack estavam revoltadas com a invasão do "ponto" da Estação da Luz por mulheres mais jovens que trabalhavam em hotéis nas imediações do Largo do Arouche que haviam sido interditados pela prefeitura, tirando conseqüentemente os clientes das que já faziam "ponto" na Estação. Falaram com a coordenadora da casa para Ihes dar folhas de sulfite com o propósito de fazer um abaixo-assinado para tirar as mulheres novas da área delas.

Já não basta as crackeiras tirarem nossos clientes. Elas são demais desvalorizam a gente, fazem serviço completo por 5 reais, só pra comprar pedra. Nem tomam banho e conseguem nossos cliente, porque fazem mais barato.

A coordenadora thes disse que não faria sentido fazer um abaixoassinado, porque não teriam a quem entregar, e as outras mulheres não sairiam só por ver as reinvindicações no papel e lhes disse para buscarem 
um entendimento sem uso da violência. Algumas mulheres disseram que já estavam "juntando uma turma" para expulsá-las de lá.

A partir dessas falas as mulheres não mais se referem as "invasoras" e passam a falar apenas das dificuldades trazidas pelas "crackeiras" como se fossem a única causa dos problemas por que passam, até porque dentro das hierarquias estigmatizantes as "invasoras" estariam ocupando um posto mais elevado do que elas, e as "crackeiras" estariam no posto abaixo de ambas, logo podendo ser as depositárias de todos os sentimentos de impotência e desqualificação.

As relações e conflitos que surgem de uma atividade que não é formal e não se tem a quem reclamar resta a resolução através da intimidação e de formas violentas de ação. Muito embora, o instrumento do abaixo-assinado possa ser visto como um símbolo de se empreender uma luta através dos direitos.

(....) quando passávamos pela estação vimos uma mulher com quem havíamos conversado, que falava muito baixo como se fosse indefesa e muito doente, andando com todo o vigor em direção ao metrô junto com outra. No caminho ambas pegaram um pedaço de madeira que estava no lixo amontoado na calçada. Chegando ao metrô esta mulher gritou em tom ameaçador: "tem mulher demais aqui, mais não vai ficar mais nenhuma".

As mulheres consumidoras que se prostituem terminam tendo um duplo estigma. Pelos consumidores de crack, por se prostituírem e pelas mulheres que fazem programa por se "trocarem por pedras" e depreciarem 0 preço do "programa". Estas são chamadas, pejorativamente pelas primeiras, de "nóinhas" nome que vem de paranóia um dos efeitos adversos do consumo do crack. Além de desvalorizar o preço do programa, as mulheres que são consumidoras, podem "fazer programas" sem o uso do preservativo, o que é um atrativo para os clientes. E estes, passam a cobrar das outras mulheres que façam o mesmo, e como para ambas o fator financeiro é sempre desesperador o uso do preservativo passa a ser facultativo, ou seja, 
de acordo com a necessidade momentânea se fará ou não sexo com preservativo aumentando, assim, à exposição para as DST's/AIDS.

Cabe ressaltar que não se deve creditar a responsabilidade do não uso do preservativo apenas às mulheres usuárias de crack. Esta é uma prática dos dois grupos, tanto no que se refere às necessidades financeiras, amorosas e às de representações do processo saúde-doença, em que "doença que não se vê não se tem", presentes no universo das classes populares de onde estas mulheres se originam. Ainda deve-se levar em conta que as próprias mulheres quando mencionam que o "movimento anda muito fraco" julgam que a crise econômica é um dos fatores que explicaria tal fato.

Os homens pagavam a gente com o dinheiro das horas extras, que era pra não mexer no dinheiro que tinha que levar pra família. Hoje se tem emprego não tão fazendo mais extra, então ele não vai mexer no dinheiro da família.

Portanto, o conflito que se estabelece não tem no uso de crack seu principal responsável, antes faz parte de múltiplos fatores que interferem nesse meio.

\section{Estratégias para conseguir dinheiro}

Nesse espaço, os vários atores desenvolvem diversas estratégias de obtenção de dinheiro, desde "fazer programas", roubar, esmolar, traficar ${ }^{13} \mathrm{e}$ recolha de latas de refrigerantes e papelão. Essas estratégias são utilizadas pelos dois grupos, bem como, para outros atores que transitam pelo circuito. Interessante destacar que existe uma escolha e produção para a utilização de algumas das estratégias descritas. A utilização de uma em detrimento de outra vai depender da pessoa a ser abordada, de como ela foi percebida dentro do circuito. Se é do "pedaço", ou se não é, se está atenta ou

\footnotetext{
${ }^{13} \mathrm{O}$ tráfico em geral é mais utilizado para manter o próprio uso.
} 
distraída, se tem cara de "tia" - designação geral dada a qualquer pessoa que circule com o intuito de ajudar - se parece piedosa ou assustada, sendo que o desenrolar da ação dependerá da reação que a pessoa tiver após a abordagem.

Apareceu em minha frente um garoto de uns 9 anos. Olhou para mim. com um olhar e com tom de voz ameaçador e disse: "Dá um real aí tia!" Falei que não tinha e abri os braços mostrando que não carregava nada a não ser uma pasta, um bloco de papel e um lápis. Ele mudou a expressão e o tom de voz e disse: "Dá o relógio." Perguntei se ele conhecia a Casa Aberta, fez cara de desagrado. Não respondeu, mas ficou mais amistoso, pegou o lápis da minha mão, e começou a rabiscar o bloco de papel. Olhou para o bolso da minha calça e perguntou: "O que é isso? Perguntei: "Isso o quê? É o bolso". Ele disse: "Esse relógio é velho, deixa eu ver, me dá ele?" Falei: "Você vai querer o relógio que o meu filho me deu?" Ele foi embora gritando: "Tô muito louco, fiquei loco a noite toda". Pensei que ele realmente não estava "muito louco".

Nota-se que inicialmente tenta uma abordagem que visa amedrontar e após me enquadrar como "tia", passa a falar de forma mais amistosa para, em seguida, ir embora utilizando do recurso do amedrontamento que sabe ter efeito sobre as pessoas pelo reconhecimento do local como espaço de consumo de crack, portanto, lugar de perigo.

Com relação especificamente às mulheres da Luz, as práticas mais comuns são: "fazer programas"/roubo", roubo/tráfico, "fazer programas"/roubo/tráfico. Sobre o roubo discutiremos adiante.

Perguntei como estava se mantendo, disse que "fazia programas" e roubava não fazia mais tráfico. Perguntei quantos programas fazia por dia disse que só fazia dois.

\footnotetext{
${ }^{14} \mathrm{O}$ termo roubo está sendo utilizado sem distinção entre o emprego ou não de violência e ameaça.
} 
Perguntei como ela fazia para ter as "pedras" se não "fazia programas", ela disse que vendia pedras. Perguntei se não ficava na Crackolândia, disse que: "lá não tá legal tá cheio de polícia", então vai ao hotel busca as pedras e fumava na rua "que é bem melhor".

Venda de preservativos

Estava há um ano nas ruas da "boca do lixo". (....) Se sustentava traficando" pedras" de crack. (....) Vendia também as "camisinhas" que pegava na Casa, para as mulheres que "fazem programas" por $R \$ 1,00$ cada.

Um homem nos perguntou se não daríamos comida, falei que distribuíamos "camisinhas" para as mulheres, o homem fez um gesto de indignação e disse: "Então me dê umas 10 pra eu vender". Falei que não tínhamos mais, ele se afastou irritado."

A venda dos preservativos distribuídos nas ruas, atualmente, faz parte das estratégias para conseguir dinheiro, apesar de não trazer grandes ganhos, pois muitas mulheres os recebem.

\section{Um novo discurso normatizador?}

Durante o período da pesquisa fez-se contato com vários profissionais de saúde e técnicos de outros grupos de apoio a essas mulheres, que tinham um interesse comum: promover a saúde e defesa dos direitos dos "profissionais do sexo" buscando orientá-los para uma organização mais efetiva enquanto uma atividade profissional. Dessa forma, a categoria "profissionais do sexo" para as mulheres dessa região surge e é definida na fala dos referidos profissionais.

Esses grupos propõem discussões com as mulheres e travestis que passam, também, por caracterizar o que seria uma "profissional do sexo". Para os profissionais de saúde e técnicos de grupos de apoio, a categoria "profissionais do sexo" englobaria mulheres, travestis e "michês" que não 
roubam nem enganam os clientes e que se reconhecem como grupo, conseguindo unir-se em torno de questões comuns. Tentam dar uma organização com a lógica do mundo do trabalho.

Alguns acreditam que se as mulheres pudessem ter a atividade reconhecida como profissão, com registro em carteira - com os benefícios previstos pelo CLT - conseguiriam uma vida um pouco melhor e diminuiria o preconceito e $\mathrm{o}$ abuso de autoridade a que estão submetidas constantemente.

Em algumas reuniões quando se comentava a respeito de não se roubar os clientes, os "profissionais do sexo" presentes assumiam esse discurso, condenando os colegas que se utilizam dessa prática, mas quando encontrados em seus "pontos" ou em outros locais comentavam também já ter usado do mesmo expediente em algumas ocasiões.

Tamara (uma travesti) nos contou que trabalhava na "moral"(...), que não roubava, mas que uma vez saiu com um homem que estava muito bêbado, ela dizia pra ele: "Vai embora senão as bichas vão te roubar". Mesmo assim, o cliente resolveu ir ao hotel, chegando lá ficou com medo de ser roubado pelos seguranças e não quis descer do carro, e como terminou dormindo em suas pernas ela fez o seguinte: "Eu abri a carteira dele e tinha $R \$ 150,00$ eu peguei $R \$ 50,00$ e mais uma pulseirinha de ouro do braço dele e vendi na rua por uns $R \$ 60,00$, sai e fechei o carro. Eu peguei porque se eu não pegasse alguém ia pegar, mais eu não peguei tudo".

Contou de outra vez que um Coreano com muito dinheiro na carteira foi ao quarto com ela e dormiu, então ao invés de pegar todo o dinheiro, ela pegou só uns $R \$ 50,00$ e um cordão de ouro que ele tinha, porque tinha medo que ele fosse bom de caratê. Este cordão vendeu na rua por uns $\mathrm{R} \$$ 100,00 .

Com base nos relatos distingue-se que existe uma lógica diferente da do "mundo do trabalho", aliás, é comum muitas mulheres comentarem que 
estão "procurando trabalho", ou que quando arranjarem um "trabalho, sairão dessa vida". Nessas falas nota-se que a atividade que exercem, muito embora Ihes garanta a subsistência, não é considerada como trabalho, pelo menos, na lógica do trabalho formal. Se não participa da mesma lógica, com certeza não participa dos mesmos códigos do que seria uma conduta "profissional". Trabalhar na "moral", portanto, não tem o mesmo significado do "profissional". Trabalhar na "moral" implicaria em não fazer do roubo a única atividade, enganando clientes desavisados. O roubo seria tolerado em algumas ocasiões, como quando o cliente não quer pagar o combinado, ou quando não observa uma regra do "mundo da rua", que é a de não se colocar vulnerável, dormindo ou se embriagando por exemplo.

Relatou que saiu com um velho de 60 anos e que na hora de pagar os $R \$ 30,00$ como haviam combinado, ele só queria dar uns $R \$ 20,00$. Comentou: "o velho era fraquinho mais era renitente, eu puxava o dinheiro dele ele não me dava, aí eu tomei a carteira dele e tirei meus trinta."

(....)com as mulheres mais jovens que usam crack fazendo por $R \$$ 5,00 fica difícil conseguir clientes, então ela também roubava, "chamo o homem faço a proposta dô um abraço e pego sua carteira".

Vai dizer que não roba?! Se a mulher tá na rua e não fez nenhum programa, ela roba mesmo. Porque ela tem que comê, tem que pagá as contas.

Também é possível identificar que, em caso de necessidade, por não ter conseguido dinheiro, esse expediente também é usado com uma certa tolerância e legitimidade, pois, principalmente no caso das mulheres, acaba não ocorrendo uma ameaça, mas um jogo de sedução, em que se abraça o cliente e rouba-se sua carteira, mas, mesmo nesses casos, está implícito que quem anda pela "boca" sabe dos riscos a que está sujeito, portanto. "ficar alerta" faz parte das regras para se circular nesses locais. 


\section{Estratégias para o uso de drogas}

\subsection{Aprendizado do uso do crack}

Pelas descrições obtidas, nos relatos das mulheres, parece existir um aprendizado para o uso do crack, muito embora não o percebam nem relatem como tal. Se esse aprendizado não corresponde ao uso ritual de substâncias psicoativas já descritos em alguns estudos, também não se pode negar que exista um aprendizado menos formal, em verdade, assim como não é formal a vida e a sociabilidade na rua. As falas e observações demonstraram algumas práticas que se repetem com relação ao uso, controle do uso, e ao socorro no caso de uma overdose, ou de como evitála.

Perguntei se existia algum aprendizado para usar a pedra. Disse que: "Não. Fumo porque quero".

Pela resposta pode-se inferir que ela parece entender que se alguém a ensinou seria responsável pelo fato dela continuar usando, como é idéia corrente na sociedade de que se é levado por alguém para o uso de drogas. Por isso não responde o que é perguntado, mas o que julga que foi perguntado. Essa fala pode traduzir que existe uma escolha pelo uso da droga e pelo prazer que ela proporciona.

O primeiro contato é feito por alguém conhecido que "apresenta" a "pedra", portanto, já conhecedor de seus efeitos.

O crack é melhor que as outras drogas, você fica legal.

O crack foi apresentado a ela por uma amiga também bóia-fria da colheita de laranja como "uma droga que vai dar uma loucura e depois de fumar a primeira você já vai sair atrás de outra". Ela disse que foi assim mesmo que aconteceu. 
Ensinaram-Ihe como usar da seguinte forma: acender um cigarro, ir fumando e guardando as cinzas, colocar as cinzas no cachimbo, por a pedra em cima, acender com um isqueiro, puxar a fumaça e segurar.

Geralmente as mulheres fumam acompanhadas ou próximas de outros que estão fumando, pois no caso de uma overdose, podem ser socorridas por quem está perto ou mesmo serem avisados caso a polícia apareça. Este socorro resume-se a puxar a língua para fora se a pessoa estiver se sufocando, ou segurá-la se estiver se debatendo.

Já teve três overdoses e foi socorrida por quem estava do lado. As pessoas que estavam perto puxaram a sua língua que estava enrolando, lhe contaram que estava se debatendo, então a seguraram para que não se machucasse.

Usam sempre alguma bebida alcóolica junto. E, por isso, é muito comum ver os usuários de crack sempre com um copo na mão. Muitas mulheres dizem não gostar de bebida alcóolica ou mesmo de cigarros, mas quando fumam dizem ser necessário o seu uso. O motivo do uso do álcool é para "rebater" o efeito da pedra e molhar a boca e a garganta que ficam muito secas. O cigarro se explica porque é com as cinzas que se fuma a pedra.

\subsection{Auto-cuidados: controle do uso}

\section{"A pedra não me domina, eu que domino a pedra".}

Para as mulheres não se consumirem com o uso da pedra relataram alguns cuidados que tomam, como por exemplo, no ato de fumar tomar um copo de leite, ou ainda, fumar durante três dias e passar três dias sem fumar, sair do local em que as pessoas estão usando o crack e se alimentar rapidamente, pois, segundo elas, quando comem a vontade de fumar passa, e se não fizerem isso, voltam a fumar novamente e podem passar mais alguns dias sem comer, o que aumentaria o risco de uma overdose. "Quando a gente come, não dá vontade de fumar, mas a vontade logo 
aparece de novo. Eu tô aqui, mas já tô pensando em fumar". Nesse intervalo procuram também algum local para tomar banho e descansar, geralmente nessas horas vão até a Casa de Convivência ou outros locais de grupos evangélicos ou espíritas que funcionam em horários diferentes. Também mencionam ficar períodos de um a dois meses sem usar o crack. Quando fazem isso, ficam em casas de parentes, procuram se alimentar bem e muitas dizem usar só a maconha nessa época. Muitas das mulheres que tomam esses cuidados não se consideram dependentes do crack, outras acreditam que são capazes de usar com certo controle. O parâmetro é que não ficam pelas ruas procurando por pedras inexistentes no chão. Abaixo transcrições dos cuidados que tomam:

Eu não sou viciada, porque fico até um mês sem fumar.

Alguns dias eu volto pra casa e aí só fumo maconha e como bem.

Disse tomar os seguintes cuidados: Fuma uma semana e na outra não fuma e come, e procura não ficar perto dos locais em que se fuma e de quem está fumando, pois se passar onde estão fumando "só de ver a fumaça dá vontade de fumar de novo.

Apareceu um homem na frente da casa e pediu comida, ele estava trêmulo, ela disse: "ele também usa, eu conheço quem usa." Perguntei como ela conhecia, falou: "eu conheço". Perguntei se era por que ele estava tremendo? Ela concordou e mencionou algo semelhante a ficar "meio fora do ar". E comentou: "Ele tem que comer agora, senão não vai comer mais e vai voltar a fumar. Quando a gente come não dá vontade de fumar, mas a vontade logo aparece de novo".

Perguntei se tomava algum cuidado para usar a "pedra", respondeu: "Eu não fumo todos os dias, por exemplo: eu fumei ontem, hoje não vô fumá, amanhã eu fumo. Aí quando não fumo tento me alimentá bem e também quando fumo, às vezes, tomo um copo de leite enquanto fumo." 


\section{O tráfico como fator de controle}

Nessas estratégias verifica-se que ser traficante de pedras de crack também termina por ser um fator a mais de controle do uso. Porque não saldar as dívidas de consumo e de venda são punidas de forma exemplar (geralmente com a morte).

Não sou viciada, nem posso ser, senão fumava todas as pedras e não vendia, e é assim que eu me sustento. Quem vende tem que ter responsabilidade.

Nota-se aqui o emprego da palavra "viciada" para designar o não controle, ao mesmo tempo que o opõe ao termo responsabilidade e ter responsabilidade implica uma diferenciação no uso do crack, uma qualificação do usuário em relação aos demais.

A pedra não me domina, eu que domino a pedra.

$\mathrm{Na}$ fala está implícita a idéia de que o uso do crack é capaz de fugir ao controle, e que se para algumas pessoas é verdade, para quem consegue não se deixar "dominar" é motivo de certo orgulho, mas esse orgulho também é influenciado pela noção que é veiculada pela mídia de que o crack é devastador, e que conseqüentemente circula entre a população de uma maneira geral.

Eu não trafico, porque tenho medo de não me controlar, fumar tudo e ter uma overdose, já tive três.

Outro ponto que essa fala levanta é que, para algumas pessoas, ter maior quantidade disponível poderia levar a um não controle do uso vindo a sentir os efeitos adversos, pois enquanto buscam pela pedra não a utilizam. E esse período, apesar de não ser pensado para isso, proporciona uma descontinuidade do uso, podendo inclusive buscar comida ou algum cuidado para o corpo. 


\section{Reconhecimento de que pode ter uma overdose}

Também nota-se nos relatos que, com o aprendizado do uso da substância, adquire-se também conhecimento sobre os efeitos adversos e de como preveni-los.

Gabriela disse que estava na Luz desde sexta-feira e que estava pipando desde então, comentou: "Tô quase tendo uma overdose, olha como tá inchada (mostra a garganta que realmente estava inchada, ela estava trêmula). Tô desde sexta-feira sem comer nada só pipando e bebendo água". (é segunda-feira) Gabriela comentou: "tem gente que fica na "nóia" catando coisa do chão, mas eu não, eu fico legal."

"Conheci o crack quando era feito da farinha, na colher". (pensei que então deveria usar há mais de 2 anos) Em uma roda de 20 chegavam a fumar umas 100 pedras. Pergunei como the falaram da pedra para que experimentasse, se ensinaram como usar. Disse que ninguém falou nada, simplesmente fumavam. "Chegavam na roda cantavam e fumavam."

Falou que gostava de usar a pedra e ficar "curtindo o efeito."

Interessante observar que esses relatos do uso estão em desacordo com a imagem demoníaca do crack como motivadora de comportamentos violentos. Esses relatos são acompanhados de expressões de quem recorda uma experiência agradável e tranqüila, com olhar ao longe e sorriso nos lábios.

\subsection{Hábitos associados ao uso de crack}

A maioria das mulheres que usam o crack referem-se a ele sempre de modo negativo, ou como sendo responsável por levá-las a fazer coisas que não fariam se não o tivessem usado. "Essa pedra é maldita" "Ah, cê fumô, parece que a pessoa é o diabo, que você tem que matar". "Cê fumô, parece que a pessoa tá olhando muito pra você, você já pensa que é da polícia." "Não gosto da pedra". "Quando estou usando pedra, apesar de odiar usar 
álcool e cigarros, eu fumo e bebo". Uma delas quando questionada por que usava se não gostava respondeu: "Faz parte".

Portanto, podemos inferir que "Faz Parte" significa a adesão ao circuito da rua, a uma identidade pertencente a esse espaço e em que o uso de drogas e os comportamentos violentos são formas de expressão e de construção de uma identidade de exclusão.

"Identidade e exclusão também dizem respeito a uma condição interativa e às formas como a sociedade dominante, incluída, lida com aqueles que não se identifica. As idéias de exclusão e de identidade não podem ser pensadas como opostas, mas como entidades que se justapõem, se interpenetram, etc., e daí pode-se pensar a própria exclusão como um móvel a partir do qual se constrói uma identidade (ADORNO 1999, p. 93)".

Sobre como usa a droga comentou: "quando estou fumando pedra apesar de odiar álcool e cigarros sempre bebo cerveja e fumo cigarros porque tenho que juntar as cinzas para acender as pedras".

Uma das mulheres que dizia não gostar de álcool relatou que quando começavam a fumar e todos bebiam pinga ou cerveja para cortar o efeito da pedra ela usava água, refrigerante ou leite. Sobre as pessoas preferirem usar a pedra em grupo para se protegerem, comentou que ela preferia usar só com uma pessoa e que as pessoas, de uma forma geral, usam acompanhadas porque sabem do risco. Quando questionada se seria o da polícia aparecer ou de uma overdose disse que "não", mas não explicou, ou não conseguiu explicar o que era esse risco.

\section{Predileção por "pedra" ou outra droga.}

Os relatos também demonstraram que existe uma escolha da droga, baseadas nos efeitos que consideravam mais agradáveis.

Falou que preferia a "pedra" a outras drogas, porque ficava melhor com ela. Disse que os irmãos falam para ela largar a "pedra", mas ela não 
quer. "Não sei, dá uma vontade de fumar então eu saio pra rua pra fumar, gosto de fumar a pedra e ficar curtindo o efeito".

Ela não gosta de maconha e o crack foi a primeira droga que experimentou, disse que tem heroína nas ruas, mas que nunca experimentou.

Também existe a possibilidade de uma má experiência fazer com que a pessoa passe a não usar mais a substância.

Eu gosto de qualquer tipo de droga, só não gosto do crack. Quando eu usei pela primeira vez passei muito mal, então eu não fumo mais.

\subsection{A nóia: efeito não desejado}

O termo "nóia" é a designação dada para um dos efeito adversos do uso do crack, que é o de acreditar que algo ou alguém irá Ihe fazer mal. Em vista desse sentimento persecutório, o usuário fica alerta e pronto para se defender.

Ela disse não gostar de crack: "Essa pedra é maldita”. Comentou que se cuida, procura se alimentar bem, não saberia dizer por que fuma "pedra", não gosta de pedra, porque: Cê fuma uma "pedra" e já acha que o primeiro ser humano que passa é inimigo, ô tá olhando muito pra mim, alguém vai me pegar, essa pessoa é da polícia. Ah se fumô parece que a pessoa é o diabo, você tem que matar. Gosto é de uma macoinha, com maconha cê fica legal". Ela mora na rua do Triunfo na "Boca do lixo" contou que à noite não se pode dormir, pois os donos da rua jogam gasolina e põem fogo. Disse que os donos da rua eram: traficantes, cafetão, policial.

Disse que no sábado roubou 15 reais de um homem e que no domingo "ficou na nóia do cara" achando que ele iria aparecer, "mas depois passou" fala tranqüila.

Em um outro relato, Paola conta que usou crack durante quatro anos aproximadamente. Iniciou o uso com 4 pedras e após quatro meses passou 
a usar 15 a 20 pedras por dia. Antes de usar o crack, usava e traficava cocaína.

Questionada se existiu algum ensinamento para usar o crack sem entrar na "nóia", disse que não, que dependeria de como cada pessoa lida com a "pedra". Descreveu uma estratégia para evitar a "nóia": observar as próprias reações, por exemplo quando fumava 5 "pedras" seguidas e notava que estava ficando muito agitada, saía do local onde estava fumando, tomava algumas cervejas e depois voltava a fumar.

Informou que está há três meses sem fumar crack, porque decidiu que vai parar. Indagada sobre como controlava a vontade de usar o crack, disse: "quando tenho muita vontade eu cheiro farinha".

Os relatos demonstram que o aprendizado de como utilizar a substância buscando evitar os efeitos adversos se dá pela percepção corporal e pela observação das práticas utilizadas pelo grupo. A partir dessas observações e experiências empíricas que são testadas em conversas do dia-a-dia - por isso não atribuem caráter de aprendizado - vai se constituindo uma cultura da droga como já descrito por Becker (1977) que subsistem a idéia circulante da irreversibilidade e total falta de controle do uso do crack e do efeito "nóia".

Nota-se também a reflexividade de que GIDDENS (1996) fala, pois a palavra "nóia ou nóinha" é o diminutivo do termo médico-psiquiátrico paranóia que designa, entre outros sintomas, o delírio persecutório, presente em várias psicopatologias.

Também cabe dentro dessa designação o não controle sobre a droga, ou seja viver inteiramente para ela, não conseguindo em nenhum momento sair em busca de um cuidado para o corpo, ou de dinheiro para assegurar o consumo, passando a procurar pedras inexistentes pelo chão.

\footnotetext{
${ }^{15}$ Uma das gírias utilizadas para designar a cocaína.
} 
Cabe ressaltar que a "nóia", como bem explica ZIMBERG (1984) em seu estudo no qual desenvolveu o esquema de "Set e Seting", sem minimizar o efeito da substância no organismo, vai demonstrar como o ambiente físico e social onde ocorre o uso e o estado psicológico do indivíduo irão influenciar nos efeitos da substância. Analisando as regras que regem o espaço da região pesquisada, verifica-se que o esquema de ZIMBERG ajuda na compreensão do efeito "nóia", pois que uma das estratégias de conseguir dinheiro tanto para as mulheres que usam crack, como para as que não usam, seria a prática de roubos. Como elas ficam no mesmo "ponto" (no caso das mulheres que "fazem programas") ou circulando pela região, sempre temem pela volta do cliente ou homem que roubaram, pois acreditam que é mais fácil serem reconhecidas por eles do que reconhecê-los. Outra estratégia de se conseguir dinheiro que também não é isenta de perigos é o pequeno tráfico de crack de que se valem para conseguir sustentar o próprio consumo, além da "responsabilidade" de ter de prestar contas ao traficante existe o perigo real de serem pegas pela polícia. A ação da polícia pode ter duas variáveis que são: ou serem extorquidas, levando as "pedras" e/ou dinheiro, o que acarretaria problemas também com o traficante, ou serem levadas para delegacia, podendo ser, autuadas ou liberadas, possibilidade que vai depender do entendimento do delegado de plantão, se são ou não traficantes, pois geralmente são pegos com quantias muito pequenas. Portanto, pode-se pensar que o efeito "nóia" também está associado a acontecimentos reais e também a resposta físico/psicológica de cada indivíduo, como demonstram alguns relatos.

\subsection{Diferença entre homens e mulheres no uso e tráfico de} crack

De maneira geral, as diferenças entre homens e mulheres no pequeno tráfico - que fazem os consumidores - não foram observadas.

Perguntei se faziam diferença entre as mulheres e os homens para venderem as pedras; perguntei se preferiam os homens às mulheres para 
vender as pedras, comentei como em toda a profissão que mulher é deixada de lado, sorriem e dizem que não. Gabriela disse: "tem que ter responsabilidade".

Mas no que se refere ao consumo em geral, relatavam que as diferenças eram mais individuais do que por sexo. Apesar de neste circuito ter sido observado que as mulheres usam do expediente de trocar sexo por crack, comportamento que não foi verificado entre os homens que circulam na região.

Perguntei se mulher que usava crack se acabava mais do que $o$ homem. Ela acredita que sim e foi veemente: "se acabam muito mais. Mulher fica dormindo pela rua, não come, não goza. Homem não, ele goza, passa as pedras, come." Falei: mas os homens não se prostituem, não é? Me disseram que eles não conseguem ficar com o "pinto duro". Disse: "Magina eles transam bastante, tá vendo aquele menininho ali, ele é o maior taradinho, até pro meu lado ele vem. As mulheres fazem com eles até por uns farelos de $R \$ 1,00 . "$

Perguntei se as mulheres se prostituem mais que os homens quando fumam, ela não soube dizer, mas comentou que as mulheres acabavam fazendo "chupeta ou um programa até pelos farelos de $R \$ 1,00$."

\section{Estratégias de obtenção do crack}

O tráfico sempre é pequeno não sendo a única estratégia de conseguir dinheiro. Quando o pequeno traficante chega à rua com o crack, estabelece-se uma espécie de feira, com os consumidores que não tem dinheiro oferecendo o que tem para conseguir uma "pedra", pelo menos. Se oferece desde roupas, bonés, blusas e outros objetos, todos usados, conseguidos por doação de alguma entidade filantrópica, por troca ou mesmo roubo.

Outra oferta freqüente é a troca de sexo por pedra, como parece ocorrer em várias partes do mundo. Essa prática é feita basicamente pelas 
mulheres, muitas delas já tinham a prostituição como fonte de sustento e passaram a usar o crack, outras eram consumidoras de crack, algumas delas meninas e adolescentes que estão nas ruas, que por não ter dinheiro passam a se prostituir, fato que gera conflito com as demais mulheres como já foi visto.

Outro problema para as mulheres que se prostituem e para os demais consumidores de crack é a polícia, segundo relato de algumas mulheres, que os extorque e se prestam a fazer pequenos favores para os traficantes e donos de hotéis, quando estes precisam dar "uma lição" em algum consumidor que ficou inconveniente.

\section{Os donos da rua/Como age a polícia}

Por "donos da rua" entende-se homens (geralmente) que utilizam da força física, da intimidação e da extorsão não só com as mulheres, mas com todos que estão em sua área de "atuação". Estes podem ser traficantes, seguranças privados e mesmo policias.

Disse que no domingo quase foi presa porque o policial veio pegar um menino que estava cheio de pedras e ele disse que era dela. Ela chorou, disse que não eram suas, ficou morrendo de medo mas o policial a levou para a delegacia e depois a soltou. Comentou que estava com uma pedra de $R \$ 20$ nesse dia e ficou sem.

As ações policiais na área segundo os relatos, são denominadas de "arrastão" que se constitui no seguinte: pegam todos que estão na rua, encostam na parede, revistam, batem, tomam o dinheiro e as pedras os levam para a Delegacia de Polícia - DP ficham e puxam a capivara (ficha de antecedentes criminais) e os liberam.

Estávamos na rua do Triunfo a polícia estava dando uma "blitz", passamos por eles e uma moça que vinha em direção contrária a nossa fez meia volta e começou a andar em nossa frente se escondendo da polícia, estava com um isqueiro e um copo de plástico com um pouco de bebida 
alcoólica, jogou-o no chão e nos falou: "a polícia já me levou $R \$ 50,00$, eu não vou dar mais nada pra eles."

Outra forma de atuação da polícia é a utilização de "gansos" que, geralmente, são usuários de crack, para atuarem como informantes. Como relata o trecho abaixo.

Tâmara disse que agora que a polícia resolveu pegar os traficantes não se vê mais o crack na região, apesar de nós termos visto a poucos metros dali. Comentei que as ruas estavam mais vazias, mas que morreram algumas pessoas que foram tidas como "gansos", ela concordou e disse que tinha uma mulher que é consumidora de crack e que, além de entregar os traficantes para a polícia, vai até às "bocas" junto com os policiais. Perguntei por que ela se expunha tanto, ela disse: "Porque é loca. É a troco de um pouco de pedra, logo, logo ela vai morrer. Eu já vi que tem gente atrás dela, ontem mesmo passou uma moto com dois homens procurando ela. Mas às vezes a própria polícia mata os "gansos" porque eles chegam na "boca" e combinam ganhar $R \$ 10.000,00$ do traficante para não prendê ele. Combina com o "ganso" que ele vai levar $R \$ 2$ 000,00, só que não dá nada pro "ganso", só um pouco de droga, aí o "ganso" vai trabalhar com outro policial e pode contar que foi passado pra trás por tal policial que fez acordo com o traficante, então pra não sujar o próprio policial mata o "ganso"."

\section{Situações de violência}

A violência está presente no cotidiano das mulheres podendo ser perpetrada pela polícia, clientes, traficantes, maridos e/ou cafetões e inclusive por elas mesmas. A possibilidade de um "programa" dar errado resultando em situações violentas tais como estupros, surras, tentativas de homicídio, fazem parte do risco da atividade e, muitas vezes ficam sem cuidados médicos e sem denúncia à polícia do abuso sofrido. Dentro do universo em que está inserida a prostituição - a "região moral" como proposta por PARK (1987) - em contigüidade com outros tipos de condutas 
consideradas marginais, tais situações tendem a ser naturalizadas fato que explica, em parte, muitas delas ficarem sem denúncia.

Ele pegou uma barra de ferro e bateu duas vezes em sua cabeça e mais duas vezes em seu braço e corpo e foi embora. Ela se levantou ensangüentada e saiu pela rua, ligou para o resgate e sentou na calçada, o resgate passou e não a viu, então ela foi a um bar conhecido e foi socorrida por um amigo que a levou para o hotel e a colocou debaixo do chuveiro, ficou uns dias com esse amigo até se recuperar, ficou com muita febre, se tratou tomando antibiótico e lavando os ferimentos com sabonete.

Elas relatam tais ocorrências com naturalidade e, muitas vezes, rindo. Talvez esse comportamento vise a exorcizar uma situação que apesar de ruim não se julguem capazes de resolver, portanto, o relato em tom jocoso Ihe retiraria o peso. Outro fator a ser considerado é que essas mulheres fazem parte de um "mundo masculino" em que a força física e o poder são atributos valorizados que elas não possuem, logo, se sentiriam desqualificadas perante a figura masculina justificando, assim, a violência perpetrada. Deve-se considerar ainda, que a proximidade com práticas ilegais que ocorrem nesse espaço, tais como roubo, tráfico e consumo de drogas, tornam a presença da polícia não desejada, além do fato de que suas queixas não sejam levadas em consideração parte das autoridades.

Como foi relatado anteriormente, na questão da disputa pelo "ponto" e cliente, a violência é um expediente usado entre as mulheres para garantir o seu território, bem como o roubo visando complementar seus ganhos. Os autores consultados analisam a violência praticada pelos pesquisados contra os "outros" e os "iguais" como integrante do estilo de vida na rua e manipulação do rótulo de desviante com o objetivo de conseguir reverter situações desfavoráveis.

GASPAR (1984) ao analisar a agressividade e violência das "garotas de programa" que pesquisou, concluiu que múltiplos fatores convergem para tornar a atividade de "fazer programa" uma situação passível de ser violenta. 
Um dos fatores levantados seria o de o sexo ser culturalmente associado ao domínio do instinto e oposto às normas sociais sendo percebido como animalesco, portanto, fora do controle. Logo, a figura da prostituta que se utiliza do sexo fora de tais normas estaria vinculada simbolicamente ao próprio descontrole.

"No universo analisado, onde o descontrole se associa em particular a manifestações violentas, o uso da violência é legitimado como uma forma de coerção (ou defesa). Por tais motivos uma garota corre sempre o risco de entrar numa situação violenta." (GASPAR 1984, p.98)

SILVA (1993) ao analisar um grupo de travestis da Lapa no Rio de Janeiro, seguiu a mesma linha de análise.

Constrói-se então a identidade social do travesti sob o duplo trabalho. O dele próprio em uma busca permanente da beleza, dos mais bonitos vestidos, da maquiagem mais adequada em um intenso ritmo exibicionista. $O$ da sociedade, que a cada traço da maquiagem, a cada planejamento da saia, a cada gesto, a cada palavra semitonada, reage com precisos risinhos, chacotas que energizam a todos em gargalhadas. O riso, a piada, a ironia vão envolvendo o travesti quase que em termos sensoriais, como que misturados aos vestidos as calcinhas, ao rímel, num trabalho insidioso, penetrante, dissolvente. $O$ travesti tem dupla pele: a de purpurina e a da humilhação. Em que ordem não se sabe. Ou talvez numa pele só tecida pelos dois ingredientes. A arma é a violência. (SILVA 1993, p.4041)

As mulheres da Luz aceitam com certa resignação sua condição de "mulher de programa" pobre, com dificuldade de incrementar seu negócio que é o da sedução, já que não podem investir em sua aparência, da mesma maneira que falam da violência e da discriminação sofrida. A analise das 
respostas violentas com que tentam resolver os seus problemas permite inferir que talvez seja a manifestação da revolta não revelada no discurso, mas constitutiva de sua identidade de desviante na medida em que absorvem a acusação social ("sou prostituta mesmo!") e não conseguem ter suas demandas atendidas.

Cabe lembrar que a condição de não cidadã ou de "subcidadão" a que estão submetidas, bem como os demais atores que circulam nesse espaço, conduz a utilização da violência como uma, senão a única, linguagem possível dentro do espaço de não pertencimento e anonimato em que a rua se constitui como bem observa DAMATTA (1985):

Mas e na rua? Bem, aqui passamos sempre por indivíduos anônimos e desgarrados, somos quase sempre maltratados pelas chamadas "autoridades" e não temos nem paz, nem voz. Somos rigorosamente "subcidadãos" e não será exagerado observar que, por causa disso, nosso comportamento na rua (e nas coisas públicas que ela necessariamente encerra) é igualmente negativo (p.16).

\section{Gênero e sexualidade}

Nota-se que nesse universo, muitas vezes, a aparência masculina é procurada, o que poderia sugerir uma busca de respeito ou uma forma de camuflagem visando uma proteção no "mundo da rua" em que a construção social do masculino parece imperar quase caricata. Muitas mulheres utilizam desse artifício, independentemente de se afirmarem como "sapatões". Muitas "fazem programa", têm maridos e mantêm essa aparência.

Cheguei a porta da estação e percebi que acontecia uma discussão entre 4 mulheres. Uma que aparentava ter uns 35 anos e as outras adolescentes, com aproximadamente 13 anos, todas negras, sujas maltratadas. Fiquei sabendo que a mulher mais velha era traficante. (....) No meio da discussão a mulher mais velha se intitulou de "sapatão" ela tinha um 
jeito bem masculinizado. As adolescentes, não dava para afirmar se eram meninas ou meninos.

Carla, negra 20 anos, foi menina que viveu em situação de rua. Veio à Casa para pedir absorvente higiênico. Mostrava-se muito irritada pelo fato de estar menstruada, pois não gosta de se parecer com "mulher". Nos bazares promovidos pela Casa em que se vende roupas, escolhe sempre roupas que não sejam muito femininas. Veste-se como homem, não "faz programa" nem vende "pedras", diz que rouba para se manter.

Se aproximou mais um grupo de mulheres e, entre elas, uma que não conhecíamos e que até nos cumprimentar acreditávamos ser um homem. Ela era negra, forte e com cerca de 1,80m. Estava com uma touca-meia do Corinthias, tinha gestos masculinos. Perguntamos se ela queria "camisinhas" e ela disse que sim, mas se apressou em dizer que não fazia programas, queria "camisinhas" para poder "transar" com seu companheiro, pois havia acabado de sair da prisão e não sabia o que ele havia feito nesse período. Depois enquanto conversávamos com outras mulheres, esta mulher assaltou um homem que entrava na estação, o homem ficou intimidado e the deu o dinheiro.

Não "fazia programas" disse: "sou sapatão só transo com mulher". Questionada se não "fazia programa" com mulheres disse que não. Se sustenta traficando pedras de crack.

As identidades masculina e feminina são socialmente construídas, dessa forma, as imagens tradicionais associadas ao masculino sempre foram a do guerreiro, agressivo/violento e provedor em oposição à imagem feminina de recato, fragilidade e submissão. Portanto, espera-se respostas diferentes para situações vivenciadas em sociedade por um homem ou uma mulher.

Partindo dessa imagem o papel que a mulher ocupa na marginalidade estaria sempre associado ao de mulher de malandro ou prostituta, o que não 
Ihe conferiria o respeito às avessas que é conferido ao homem marginal como valente, capaz de tudo, pois ainda estaria atuando dentro da fragilidade feminina. Alguns criminalistas do início do século chegaram até a difundir a idéia de que a prostituição era a única possibilidade feminina de criminalidade, por fraqueza física e falta de inteligência para cometer crimes. (como já mencionado no corpo deste trabalho).

Nas ruas da região da Luz a masculinidade é reinterpretada da maneira mais caricata. Busca-se com isso angariar um diferencial de poder que se operacionalizaria para aparentar maior valentia, quando em meio de uma briga dizem: "sou sapatão", ou quando se intitulam dessa maneira para demarcar sua preferência sexual, que carrega um atributo de valor com relação às outras mulheres, pois não seriam passivas, papel atribuído ao gênero feminino nas relações sexuais e de caráter depreciativo. Da perspectiva das mulheres que se utilizam dessa aparência sem necessariamente assumir uma opção homossexual, verifica-se que é uma estratégia que garante $o$ anonimato quando cometem algum roubo afinal como no caso do assalto descrito anteriormente, se daria queixa de um homem; outra utilidade que poderia se pensar é a de que essa aparência dificultaria a possibilidade de sofrer abusos sexuais. Observa-se nesse espaço muitas meninas e adolescentes agindo dessa maneira. Alguns casos que foram acompanhados ao longo do trabalho de campo foram emblemáticos. Cita-se como exemplo, o de uma adolescente que, quando das primeiras vezes que foi encontrada, apresentava-se com roupas, cabelos e forma de se portar bastante feminina, com o passar do tempo e quanto mais se embrenhava no "mundo da rua" era encontrada com estilo de roupas unisex - que são unisex justamente por não possuir signos femininos - e os cabelos com corte cada vez mais curtos. Em dado momento acreditou-se que ela não freqüentava mais o local, mas, ao contrário, além de assumir totalmente os signos masculinos estava também vivendo nas ruas; pouco tempo depois foi localizada no Cadeião de Pinheiros, presa por roubo. 
O percurso percorrido por estas mulheres até este travestir-se do masculino compreende-se na medida que o caminho posto, é o da delinqüência da marginalidade que é majoritariamente um espaço masculino. 


\section{Imagens de saúde-doença e cuidados}

Classificou-se a análise entre imagens do corpo e AIDS e uso do preservativo. É interessante observar que as percepções sobre saúde doença, principalmente a AIDS, está muito associada à aparência física, ou seja, ser magro é sinal de pessoa doente e estar gordo sinal de pessoa sadia. Algumas mulheres sabidamente soro-positivas e com AIDS não conseguem acreditar que estão doentes ou que sejam portadoras do vírus, por estarem gordas e se curarem de gripes e machucados rapidamente.

Eu não posso ter o vírus, tô gorda e não tô doente, sarei de uma tuberculose.

Com relação à AIDS e qualquer outra doença, nota-se que partilham da mesma noção de que doença que não se vê não se tem. Algumas mulheres por não ter sintomas visíveis da AIDS não se consideram doentes e/ou portadoras do vírus, mesmo de posse de resultado positivo da doença.

Então ela contou que tem AIDS e que acha que seu companheiro também tem. Ela disse que fez o teste há 1 ano em Araraquara, sua mãe leu o resultado e sofre muito por isso. Demonstrou certa dúvida de que tenha realmente a doença: "Mas eu não fico doente, tive gripe mais sarou, falaram que quem tem AIDS não cicatriza as feridas, mas olha como cicatrizou as minhas (mostra marcas de feridas nos pés).

O último companheiro era usuário de cocaína injetável e morreu de AIDS aos 22 anos. (....) Nos últimos 6 meses esteve internada em um hospital para presos, com tuberculose (mostrou uma cicatriz de cirurgia recente para tirar "água do pulmão"). Disse que seu teste de AIDS deu inconclusivo, e não acredita que tenha o vírus porque "estou gorda não posso estar doente."

Nota-se também que a imagem do paciente de AIDS que se fixou no imaginário, ainda é a da pessoa muito magra e cheia de feridas, portanto, 
por essa lógica quem não tiver tais sinais não pode estar doente. Por isso mesmo as usuárias de crack, muitas vezes procuram ficar um tempo sem consumir para não ficar muito magras, aparentando ter AIDS o que poderia afastar os clientes e também porque um corpo muito magro não parece ser apreciado pelas mulheres e também pelos clientes. É muito comum ouvir as expressões: "eu nem tinha corpo" ou "antes eu tinha um corpão", referindose às formas mais arredondadas.

A imagem do gordo como sinônimo de saúde repete-se em várias circunstâncias.

Com relação aos danos à saúde do bebê provocados pelo uso do crack pela mãe segue-se a mesma lógica:

Cássia, que disse estar grávida de nove meses (é usuária de crack), não acreditava que usar crack durante a gravidez pudesse fazer mal a criança, porque uma amiga usou até hora que foi para o hospital e a criança nasceu com $4 \mathrm{~kg}$.

Nota-se a crença no leite como um alimento que desintoxica, como mencionado em algumas falas dessas mulheres, que quando querem tomar algum cuidado com o uso do crack o utilizam conjuntamente.

(...) às vezes tomo um copo de leite enquanto fumo.

Perguntei se ela não tinha medo de pegar AIDS "transando" sem camisinha, ela comentou que sabia ver quando o cliente estava doente. Perguntei como e ela respondeu: "se o cliente é limpinho e é casado, porque ele não vai querer passar doença para a mulher dele."

\subsection{Imagens sobre AIDS}

Optou-se por este título porque toda a informação sobre AIDS que circula entre as mulheres passam pelo filtro das imagens corporais, ou seja, as doenças deixam evidências no corpo, portanto, alguém com doença grave deve, no mínimo, parecer abatido e magro. Por outro lado, nota-se 
que algumas informações veiculadas pelas campanhas de prevenção da AIDS e pelos profissionais de saúde circulam entre as mulheres sendo expressas de maneira correta, muito embora, tal fato não se mostre suficiente para a incorporação de hábitos preventivos, como o uso do preservativo por exemplo. Porém, algumas informações sobre recontaminação pelos parceiros, no caso da AIDS, e sobre sintomas e tratamento, no caso da sífilis, ainda não estão suficientemente difundidas.

Outra mulher jovem e arrumada aproximou-se e nos perguntou se éramos os espíritas que davam lanche, respondemos que não, falamos das "camisinhas", ela disse que não precisava porque tinha parceiro fixo, comentamos em tom jocoso que é aí que mora o perigo, então ela nos contou que era soropositiva e que o companheiro também, e por isso não fazia mais "programas" porque tinha medo de contaminar os outros. Comentei que mesmo ela e o parceiro sendo soropositivos teriam que continuar usando a "camisinha" para não se recontaminarem aumentando $o$ número de vírus no corpo, ela disse; "Ah, eu não sabia".

Reconheci uma moça que freqüentava a Casa de Convivência, (...) esta pediu "camisinha", e para conversar com uma amiga que estava com sífilis e não queria se tratar. (...) Conversei com a moça doente que se chamava Kelly, que disse que foi ao posto, tomou remédio por uma semana e que "sarou", foi dito a ela que o fato de ter desaparecido os sintomas não é sinal de que já esteja curada e que, portanto, deveria continuar o tratamento.

\section{Uso facultativo do preservativo}

O preservativo nesse espaço tem muitas utilidades. Para os agentes de saúde, ONGS e grupos religiosos que desenvolvem trabalhos com estas mulheres funciona como um agente facilitador de entrada nesse espaço. Para as mulheres que não "fazem programas" serve como possibilidade de ganhar algum dinheiro, pois vendem por $R \$ 1,00$ cada. Para as que "fazem programas", uma possibilidade de economizar o dinheiro que seria usado para a compra, muito embora o seu uso seja facultativo, pois se arrumam 
um "marido" ou se o cliente for antigo deixam de usar. Se estão na fissura pela pedra não se incomodam de não usar se o cliente não quiser ou não pedir. Apesar de possuírem algumas informações incorporadas de como usar a "camisinha" (como colocar e retirar), esse saber não se mostra suficiente para mudarem de comportamento, e como só acreditam em doenças que possam ver, os cuidados com a AIDS ficam muito comprometidos. A informação sobre a recontaminação também não foi incorporada como demonstra fala de uma mulher que é soro - positiva e não usa "camisinha" com o seu parceiro.

Rose, questionada se usava "camisinha" respondeu que não. Comentou que as mulheres que "fazem programa" usam. E perguntou: "mas se a pessoa já está contaminada do que adianta?" Explicou-se a ela sobre a recontaminação. Então ela contou que tem AIDS e que achava que seu companheiro também teria. (....) O companheiro não fez o teste, mas ela acredita que ele tenha porque "transam" sem "camisinha". (....) Disse que o avisou, mas ele não se importou e comentou: "não enganei ninguém".

Perguntei se Rute usava "camisinha" sempre, ela disse que quando o cliente pede para não usar ela não usa e ele dá $R \$ 5,00$ a mais.

Se o uso de crack leva ao freqüente descuido no uso do preservativo aumentando a vulnerabilidade para as DSTS/AIDS, cabe ressaltar que esta é uma prática que também ocorre no grupo de mulheres não usuárias, de acordo com a necessidade, visto que são mulheres de extrato socioeconômico baixo e que, por isso mesmo, se inserem na baixa prostituição. Por outro lado, o crack se caracteriza por ser a droga dos pobres e também de fácil negociação, (apesar de sua manutenção se tornar cara) sendo propícia à circulação entre essa população .

Ainda sobre o uso facultativo de "camisinha", uma hipótese que se deve considerar é que em uma atividade como a da prostituição em que um ato da intimidade é feito com qualquer pessoa e com uma certa exposição pública dos entendimentos que o antecedem. O diferencial que garantiria a 
intimidade com os parceiros em que a afetividade esteja envolvida se daria justamente pelo não uso do preservativo.

\section{Auto-medicação/alternativos}

Maria contou que estava fazendo um tratamento à base de ervas, para um câncer de útero que tem há 5 anos e que, como passou por três hospitais (Santa Casa, Instituto de Oncologia e Hospital das Clinicas), e não a operaram e o tratamento dificulta a ela conseguir um emprego, deixou de se tratar em hospitais e está seguindo um tratamento que leu em um livro de um padre, que tem relatos de pessoas em fase terminal que passaram a se cuidar com um chá à base de babosa, mel e conhaque e que se curaram. Ela diz: "É como uma simpatia, você tem que tirar a babosa no escuro, colocar em um vidro escuro com um pote de mel e um copo de conhaque, toma durante dez dias e descansa por dez dias, até se curar. Tem que acreditar e Deus faz o resto".

É muito comum a atribuição de causas sobrenaturais às doenças, por mais que os indícios clínicos provem o contrário. É comum as mulheres que têm o agravamento de doenças crônicas creditarem isso a "coisa feita". Nesse universo, muitas vezes, são utilizados os medicamentos alopáticos e "simpatias" chegando muitas vezes a se abandonar o tratamento médico e ficar só com os alternativos ou se auto-medicar, já que se desenvolvem os mesmos sintomas de uma doença que já tiveram ou de alguém que já teve, julgam que a origem deve ser a mesma, portanto, o mesmo remédio poderia ser utilizado. Cabe ressaltar, porém, que a utilização de remédios alternativos em muitos casos é motivado pela dificuldade de acesso aos serviços públicos, pela demora de atendimento, o preço e a duração do tratamento proposto. 


\section{Considerações Finais}

Conforme exposto anteriormente, a relação prostituição e drogas não se constitui em um fenômeno recente, porém, com o advento do crack, percebe-se a ocorrência de certa deterioração na qualidade de vida das mulheres que se tornaram consumidoras deste tipo de droga, levando a uma maior exposição para as DSTs/AIDS.

Por outro lado, a discussão sobre uso de crack não consegue ficar isenta do caráter sensacionalista que cerca a polêmica sobre o uso de drogas de uma maneira geral. Dessa forma, corre-se o risco de ver o problema com proporções maiores do que as reais, dificultando o encontro de alternativas para lidar com a situação.

Deve-se considerar que não existe um único, mas diversos usos de drogas, e levar em conta as diferenças e multiplicidade dos indivíduos e o significado atribuído ao uso.

Com base no pressuposto de que o uso de drogas é um fenômeno bio-psico-social e que não deve ser encarado levando em conta apenas um de seus aspectos, procurou-se, neste estudo, desconstruir a idéia de que o uso do crack se daria sem nenhum controle por parte dos envolvidos nesta prática, tornando-se assim um caminho inexorável.

É muito propalada a noção de que não se pode pensar no uso de drogas sem se levar em conta a dimensão social; porém na prática, essa não é observada, como se o indivíduo ficasse totalmente tomado pelo efeito farmacológico da substância, não havendo espaço para manifestação de sua vontade. No caso do crack, em especial, essa é uma imagem bastante difundida. Este, na atualidade, passou a ser visto como a reencarnação do mal, ou como bem coloca ZALUAR(1994) - com relação as drogas de forma geral - o "reencantamento" do mal.

O nome crack é muito mais devastador no discurso do que na farmacologia, pois o éter, o bicarbonato ou qualquer outra substância 
adicionada não aumenta seu efeito ${ }^{16}$. O que lhe dá maior potência é a via de administração na qual se consegue maior absorção da droga, fato que não ocorre na forma aspirada devido a perda da substância nas mucosas, por exemplo. Não se pretende dizer com isso que o seu uso seja inofensivo ou isento de riscos, mas que a imagem devastadora veiculada reforça a marginalização aumentando ainda mais a distância entre os usuários e os não usuários; sendo, os segundos, elo importantíssimo em uma perspectiva de inclusão sem a qual não se conseguirá minimizar os efeitos danosos de sua utilização, e que está presente em algumas propostas de intervenção como a de "redução de danos".

Esta proposta passou a ser mais conhecida a partir do advento da AIDS devido a contaminação de usuários de drogas injetáveis (UDIs) pelo HIV, mas pode ser utilizada para drogas lícitas e ilícitas, visto que seu objetivo principal é a minimização do dano eventualmente provocado pelo uso de drogas tanto para o indivíduo como para a sociedade.

"A redução dos danos decorrentes do uso de drogas tem origem no Relatório Rolleston, de 1926, que concluía que a manutenção de usuários por meio do emprego de opiáceos é o tratamento mais adequado para determinados usuários (O'HARE 1994, P. 66)".

Nesta proposta, pressupõe-se que o uso de drogas, ou sua continuidade, - em que pese os problemas sociais e de saúde que possam estar associados - em alguma medida, também é desejado pelo usuário. Com vistas neste fato, trabalha-se sem julgamentos morais buscando a aproximação do usuário para formas de uso menos danosas à sua saúde e buscando que este desenvolva maior controle sobre seu uso. Em alguns países que desenvolvem essa estratégia com algum sucesso, tais como: Inglaterra, Suiça e Holanda, já se discute que se deve avançar na proposta de redução de danos para uma perspectiva que dê maior ênfase à inclusão social do indivíduo (RILEY et. Al. s/d)

\footnotetext{
${ }^{16}$ As substâncias adicionadas aumentam o grau de impureza e os riscos à saúde.
} 
Partindo dos princípios da "redução de danos", desenvolve-se, em Paris, uma proposta de "intervenção comunitária" que trabalha com a noção de "redução do risco", este compreendido como risco social que é o da marginalização com a conseqüente exclusão do usuário. A intervenção comunitária, no campo do uso de drogas, trabalha com o conjunto de problemas relacionados com as drogas, ou seja, os problemas sociais e econômicos que, em muitos casos, antecede o próprio uso. Propõe uma associação dos profissionais de saúde e social, dos usuários de drogas e da população pertencente ao local onde se inserem os problemas relativos ao uso de drogas, deslocando o centro da intervenção do profissional para o meio social. Não devendo nunca se separar a abordagem sanitária da “intervenção comunitária” e social (CAVALCANTI 1995). Esta abordagem tem inspiração teórico e prática no movimento da antipsiquiatria (Europa, Década de 60), nos movimentos de saúde mental comunitária (EUA, Década de 60) e na educação popular (Brasil, Década de 70).

"O eixo da "intervenção comunitária" é o do vínculo social, porque se acredita que existe um estreito laço entre a marginalização e o comportamento de risco. Ademais, a exclusão social está reforçada pelo uso abusivo de drogas associado, inevitavelmente, a uma série de problemas sanitários e judiciais (CAVALCANTI 1995, p. 9)"17

Tanto no conceito de "redução de danos" como no de "intervenção comunitária", está presente a noção de que se deve levar em conta o conhecimento do usuário e somá-lo com o conhecimento do profissional sanitário e/ou social para maior efetividade na redução dos danos à saúde provocado pelo uso de drogas.

Trata-se da construção de um novo conhecimento, elaborado a partir de um mosaico de diversos saberes: o saber dos profissionais, o da comunidade do local e o dos usuários de drogas. O conhecimento não é, pois, um

\footnotetext{
${ }^{17}$ Tradução nossa.
} 
antecedente prévio, se não um objeto por construir ou criar que se apoia sobre todos os saberes existentes, de tal forma que as metodologias e as técnicas se consideram como meios e não como um fim em si mesmo (CAVALCANTI 1995, p. 10). ${ }^{18}$

No grupo estudado, observou-se a aquisição de estratégias/conhecimentos relativos à maneira de como usar a substância de modo a não sentir ou diminuir os seus efeitos adversos.

Pelos relatos dos atores envolvidos nesta prática, notou-se que existe uma diferenciação entre os usos, ou seja, existem vários, o que os diferencia são características pessoais que se manifestam na forma como lidam com a droga. Alguns desenvolvem estratégias conscientes de controle, visando obter somente os efeitos desejados; outros se utilizam das mesmas estratégias não por opção, mas por terem dificuldade em obter, disponíveis, maiores quantidades do crack por dia, mas mesmo assim isso lhes garante maior intervalo no consumo, distanciando a possibilidade de uma overdose e possibilitando a busca de cuidados para o corpo, como alimentação, banho e descanso.

Para os profissionais de saúde e agentes sociais o desafio está posto. E para se avançar nesta questão algumas perguntas devem ser feitas. No que se refere à AIDS e às DSTs, que mensagens estão sendo passadas? Será que a forma como as mulheres se apropriam dessas informações configura uma retradução para o universo delas, em que as evidencias corporais e a afetividade fazem parte da leitura do que seja doença?

Parece que um caminho a seguir poderia ser o de se trabalhar a relação com o corpo, já que é desta maneira que elas percebem a doença e, a partir daí, pensar-se em como melhorar as práticas já desenvolvidas, tanto para o uso do crack como para as práticas sexuais.

${ }^{18}$ Idem a nota 17. 
No caso estudado, uma ação mais efetiva para a busca da saúde passa pelo exercício da cidadania e pelo fortalecimento da autonomia do indivíduo. Se forem respeitadas a escolha para o uso de drogas e a forma de viver a sua sexualidade, conseguir-se-a uma interlocução que permite o avanço para a melhora da qualidade de vida, não só no que se refere ao uso de drogas, mas também a condição de vida, de uma maneira geral, visando sua inclusão social. 


\section{BIBLIOGRAFIA}

Adorno RCF et al. O Exercício da Sensibilidade: Pesquisa Qualitativa e a Saúde como Qualidade. Rev Saúde e Sociedade. 1994; 3 (2): 172-185.

Adorno RCF. Crianças e Jovens em Trânsito para a Rua: Um Problema de Saúde Pública. Relatório de pesquisa FAPESP/Faculdade de Saúde Pública - USP, São Paulo, 1996.

Adorno RCF. Identidade e Exclusão. In: Barbosa MR, Parker R, organizadores. Sexualidades pelo Avesso: Direitos, Identidades e Poder. São Paulo: Editora 34, 1999. P. 89 - 97.

Ayres JRCM. HIV/AIDS e Abuso de Drogas entre Adolescentes: vulnerabilidade e Avaliação de Ações Preventivas. São Paulo: Casa de Edição; 1996.

Becker HS. Método de Pesquisa em Ciências Sociais, São Paulo: Hucitec; 1997.

Becker HS. Uma Teoria da Ação Coletiva. Rio de Janeiro: Jorge Zahar; 1977.

Bivar A et al. Alma Beat. Porto Alegre: L\&PM; 1984.

Bucher R. Drogas e Drogadição no Brasil. Porto Alegre: Artes Médicas; 1992.

Carneiro BHS. A Vertigem dos Venenos Elegantes. São Paulo; 1993. [Dissertação de mestrado - PUC-São Paulo].

Cavalcanti L. Toxicomanie et Travail Communautaire: du difficile art de concilier le conflictuel. Paris: Espoir Goutte d'Or - EGO, 1995

Damatta R. A Casa e a Rua: Espaço, Cidadania, Mulher e Morte no Brasil. São Paulo: Brasiliense; 1985. 
Delpirou A, Labrousse A. Coca Coke - Produtores, Consumidores, Traficantes e Governantes. São Paulo: Brasiliense;1988.

Engel M. Meretrizes e Doutores - Saber Médico e Prostituição no Rio de Janeiro (1840-1890). São Paulo: Brasiliense; 1988.

Escohotado A. O Livro das Drogas - Usos e Abusos, Desafios e Preconceitos. São Paulo: Dynamis; 1997.

Feldman S. Segregações Espaciais Urbanas. A territorialização da Prostituição Feminina em São Paulo. São Paulo; 1988. [Dissertação de mestrado - Faculdade de Arquitetura e Urbanismo/USP].

Fonseca G. História da Prostituição em São Paulo. São Paulo: Resenha Universitária, 1982.

Gaspar MD. Garotas de programa. Prostituição em Copacabana e identidade social. Rio de Janeiro: Jorge Zahar; 1985.

Gazaway P. Substance Abuse and Pregnancy. In: Queenan, JT. Management of High-Risk Pregnancy. $3^{\circ}$ ed. Boston: BlackWell Scientific Publications; 1994. p. 16-24

Geertz C. A interpretação das culturas. Rio de Janeiro: ed. LTC; 1989.

Geertz C. Estar lá, escrever aqui. Revista diálogo. 1989; 22(3): p. 58-63.

Giddens A. Para além da esquerda e da direita: 0 futuro da política radical. São Paulo: UNESP; 1996.

Guimarães LBM. História dos bairros de São Paulo: $O$ bairro da Luz. São Paulo: Pref. Municipal/Sec. de Educação e Cultura; 1971. v. 12.

Hawley TL et al. Children of Addicted Mothers: Effests of the "Crack Epidemic" on the Caregiving Environment and the Development of Preschoolers. American Journal Orthopsychiatric Association, 1995; 65(3): 364-379. 
Kearney M. Crack Cocaine and Pregnancy. Americam Journal of Nursing, 1996; mar, vol. 96: 17-19.

Korem G et al. Biological Markers of Intrauterine Exposure to Cocaine and Cigarette Smoking. In: Korem G. Maternal-Fetal Toxicology -A Clinician's Guide. $2^{\mathrm{a}}$ ed. Toronto, Canada: Gideon Korem;1994.

Leme J M. O Problema Venéreo - Estudo Hygienico Social. São Paulo: ed. Typografia do Globo; 1926.

Levi-Strauss C. Raça e História. In: Comas J et al. Raça e ciência I. São Paulo: Perspectiva, 1970. p.231-269 .

Lopez LBMA. Criminalidade e Prostituição Confinada no Município de Botucatu, São Paulo nos anos de 1962 a 1971. Botucatu, 1973. [Tese de Doutorado - UNESP]

Luiz E. Até cimento entra na mistura consumida no país. O Estado de São Paulo, São Paulo, 1999 setembro 19; cad. Especial Drogas H 4, 5.

MacRae E. A Abordagem Etnográfica do uso de Drogas. In: Mesquita F, Bastos F, organizadores. Drogas e AIDS. Estratégias de Redução de Danos. São Paulo: Hucitec; 1994. p.99 -114.

MacRae E. A importância dos Fatores socioculturais na determinação da Política Oficial Sobre o uso ritual da ayhuasca. In: Zaluar A, organizadora. Drogas e Cidadania. São Paulo: ed. Brasiliense, 1994.

MacRae E. Guiado Pela Lua. O Controle Social do Uso da Ayahuasca no culto do Santo Daime. São Paulo: IMESC; 1990.

Maffei JL. Prostituição e delito de contágio Venéreo. Porto Alegre: ed. Selbach; 1951.

Magnani JGC. Festa no Pedaço. Cultura popular e Lazer na Cidade. São Paulo: UNESP/HUCITEC; 1998. 
Magnani JGC. Na Metrópole. Textos de Antropologia Urbana. São Paulo: EDUSP; 1996.

Magnani JGC. Transformações na cultura urbana das grandes metrópoles. SP: 1996. (mimeografado)

Magnani, JGC. A rua e a evolução da sociabilidade. A cidade e a rua, Cadernos de história de São Paulo. 1993, Museu Paulista - USP. v 2.

Malinowski B. O assunto, o método e o objetivo desta investigação. In: Durham ERD, organizadora. Bronislaw Malinowiski. São Paulo: Ática; 1987.

Maurano F. História da lepra em São Paulo. São Paulo: Revista dos tribunais; 1939.

Mesquita F, Bastos F, organizadores. Drogas e AIDS. Estratégias de redução de danos. São Paulo: ed. HUCITEC; 1994.

Minayo MCS. 0 desafio do conhecimento. $2^{\underline{a}}$ ed. SP-RJ: HucitecABRASCO; 1993.

Minayo, MCS, organizadora. Pesquisa social: teoria, método e criatividade. $3^{\underline{a}}$ ed. Petrópolis: Ed. Vozes; 1994.

Moraes AE. Ensaios de Pathologia Geral - Vagabundagem, Alcoolismo, Prostituição, Lenocínio. Rio de Janeiro: ed. Leite Ribeiro; 1921.

Moraes AF. Mulheres da Vila. Petrópolis: ed. Vozes; 1996.

Mulher Libertação. Revista do Serviço da Mulher Marginalizada. São Paulo 1996; 11(44).

O'Hare P. Redução de danos: alguns princípios e a ação prática. In: Mesquita F, Bastos F, organizadores. Drogas e AIDS. Estratégias de redução de danos. São Paulo: ed. HUCITEC; 1994. 
PARK R. A cidade: Sugestões para a Investigação do Comportamento Humano no Meio Urbano. In Velho OG, organizador. O Fenômeno Urbano. Rio de Janeiro: ed. Guanabara; 1987. p.26 -67.

Perlongher N. O Negócio do Michê. A Prostituição Viril. São Paulo: Brasiliense; 1987.

Riley D, Teixeira P, Hausser D. HIV/AIDS: Questões políticas relacionadas com intervenções de larga escala para usuários de drogas injetáveis. Trad de F Aith. São Paulo: s/d. [paper]

Severino FES. Memória da Morte, Memória da Exclusão - Prostituição, Marginalidade Social e Reconquista da Cidadania. Guarulhos: Letras \& Letras; s/d.

Silva HRS et al.. Vozes do meio fio. Rio de Janeiro: Relume-Dumará; 1995.

Silva M. Traficantes são presos com $6 \mathrm{~kg}$ de pasta de coca. O Estado de São Paulo, 1999 setembro 29; cad. C 5.

Silva, HRS. Travesti: A invenção do feminino. Rio de Janeiro: RelumeDumará; 1993.

Simmel G. A Metrópole e a Vida Mental. In Velho OG, organizador. O Fenômeno Urbano. Rio de Janeiro: ed. Guanabara; 1987. p. 11-25.

Turner VW. O Processo Ritual - a estrutura e antiestrutura. Trad. de NC Castro. Petrópolis: Vozes; 1974.

Uchôa MA. Crack o caminho das pedras. São Paulo: ed. Ática, 1996.

URBS. ASSOCIAÇÃO VIVA O CENTRO. São Paulo 1999 Maio/Junho; 12.

Velho G, Viveiros E. O conceito de cultura e o estudo das sociedades complexas. Uma perspectiva antropológica. artefato jornal de cultura, ano I, n.1,1978. 
Velho G. A Dimensão Cultural e Política dos Mundos das Drogas. In: Zaluar A, organizadora. Drogas e Cidadania: Repressao ou Redução de Riscos. São Paulo: Brasiliense; 1994. p.23-29.

Velho G. Nobres e Anjos. Um Estudo de Tóxicos e Hierarquias. Rio de Janeiro; 1975. [ Tese de doutorado - UFRJ]

Velho G. O Estudo do Comportamento desviante: A Contribuição da Antropologia Social. In: Velho G. organizador. Desvio e Divergência. Uma Crítica da Patologia Social. Rio de Janeiro: Jorge Zahar, 1985. p.1-28.

White WA. A Prostituição e a Hygiene Mental. Boletim Especial da Repartição Sanitária Pan-Americana, Washington, 1925.

Williams T. Cocaïne Kids. Mesnil-sur-l'Estrée. Trad. de I SAINT-SAËNS. França: Gallimard; 1990.

Zaluar A. A Criminalização das Drogas e o reencantamento do Mal. In: Zaluar A organizadora, Drogas e Cidadania: Repressao ou Redução de Riscos. São Paulo, ed. Brasiliense, 1994. P.97-126

Zimberg N. Drug, Set and Setting. New Haven: Yale University Press; 1984.

Zuckerman B, FRANK DA. Crack Kids. Journal Pedriatrics Americam Academy of Pedriatrics. 1992 feb; 89 (1). 
ANEXOS 
A1

Anexo 1 - Mapa da cidade de São Paulo

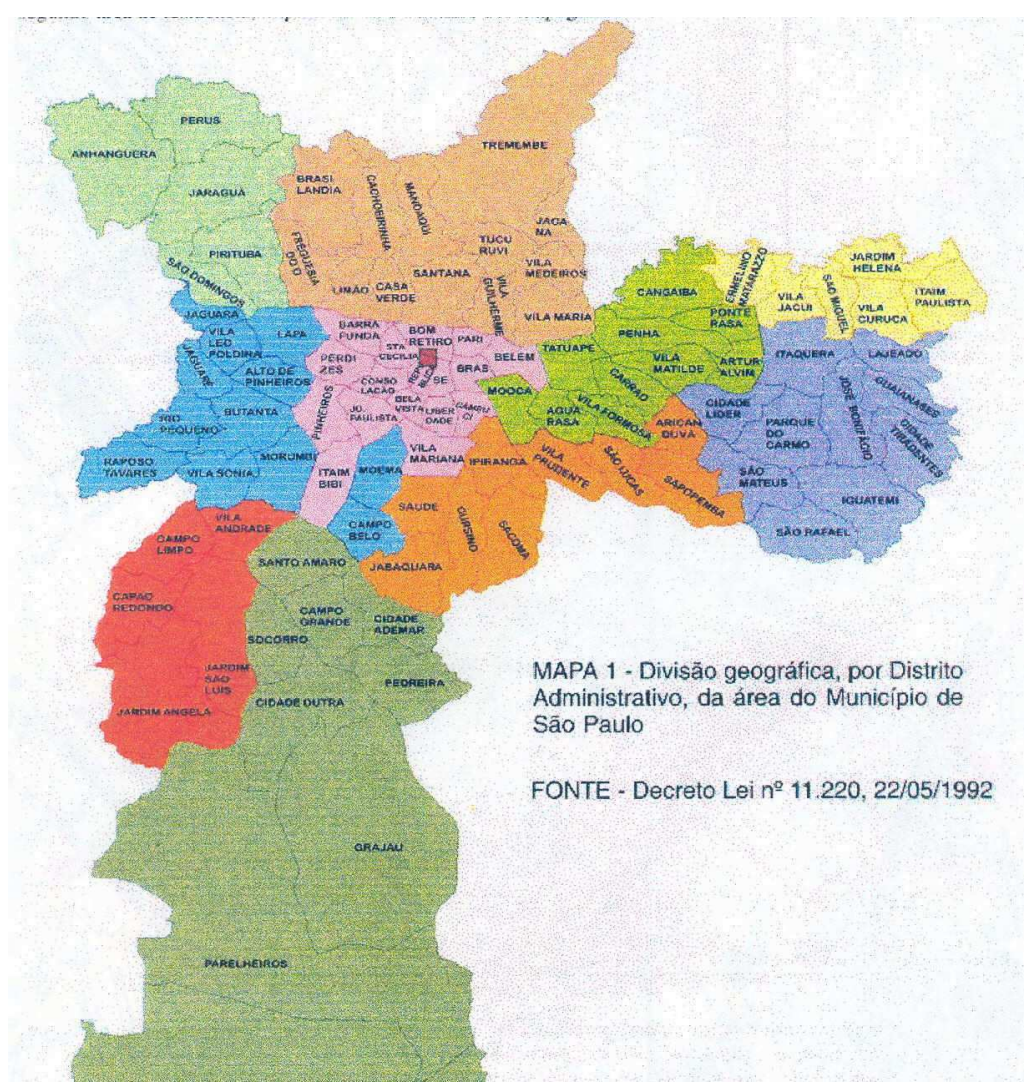


ANEXO 2- Região percorrida

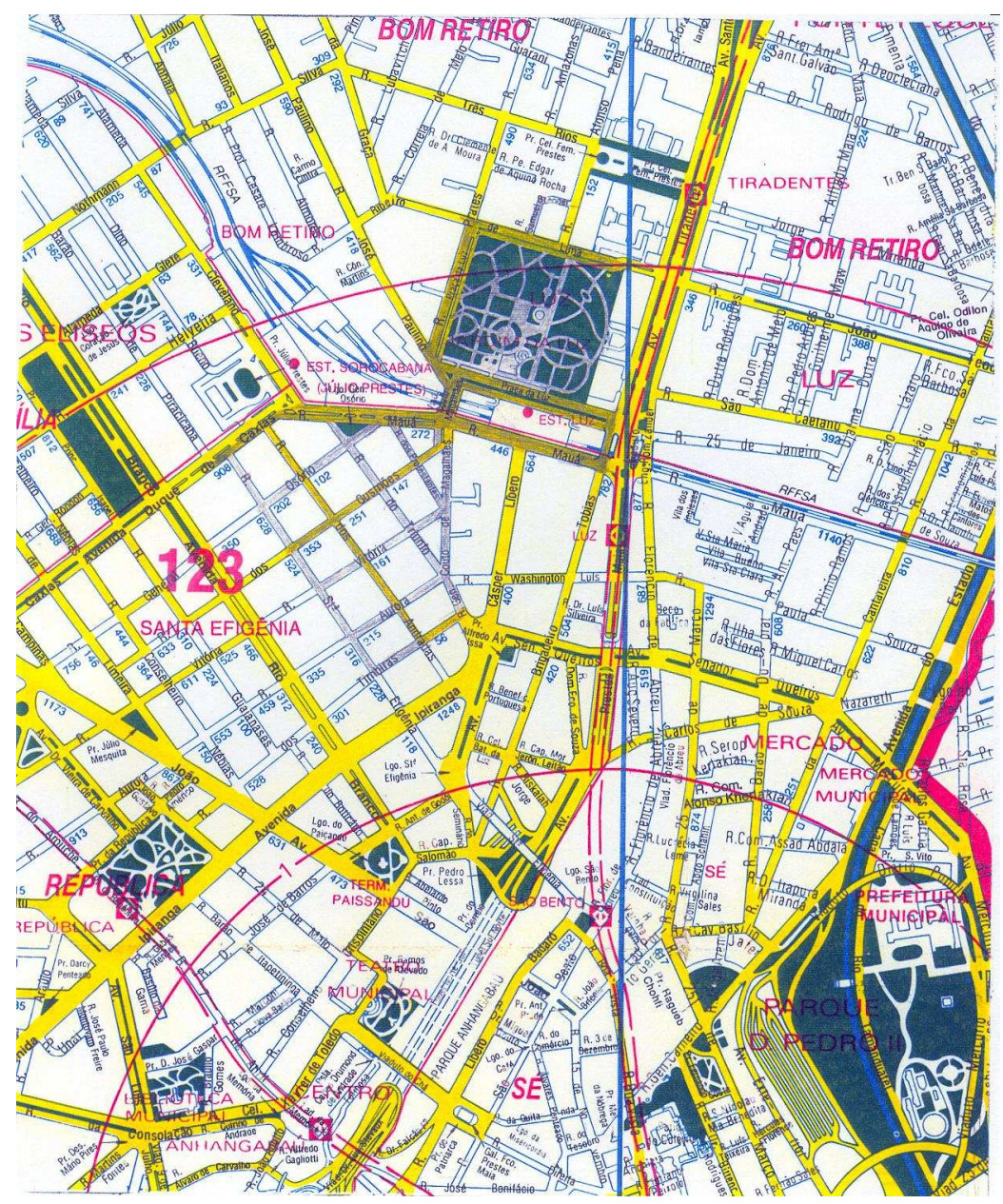

